Board of Governors of the Federal Reserve System

International Finance Discussion Papers

Number 1309

February 2021

\title{
Bought, Sold and Bought Again: The Impact of Complex Value Chains on Export Elasticities
}

François de Soyres, Erik Frohm, Vanessa Gunnella and Elena Pavlova

Please cite this paper as:

de Soyres, François, Erik Frohm, Vanessa Gunnella and Elena Pavlova (2021). "Bought, Sold and Bought Again: The Impact of Complex Value Chains on Export Elasticities," International Finance Discussion Papers 1309. Washington: Board of Governors of the Federal Reserve System, https://doi.org/10.17016/IFDP.2021.1309.

NOTE: International Finance Discussion Papers (IFDPs) are preliminary materials circulated to stimulate discussion and critical comment. The analysis and conclusions set forth are those of the authors and do not indicate concurrence by other members of the research staff or the Board of Governors. References in publications to the International Finance Discussion Papers Series (other than acknowledgement) should be cleared with the author(s) to protect the tentative character of these papers. Recent IFDPs are available on the Web at www.federalreserve.gov/pubs/ifdp/. This paper can be downloaded without charge from the Social Science Research Network electronic library at www.ssrn.com. 


\title{
Bought, Sold and Bought Again: \\ The Impact of Complex Value Chains on Export Elasticities
}

François de Soyres $^{a}$, Erik Frohm ${ }^{b}$ Vanessa Gunnella $^{c}$ and Elena Pavlova ${ }^{d}$

\section{December 2020}

\begin{abstract}
Global value chain (GVC) participation affects the relationship between trade volumes and exchange rate movements. Guided by a simple theory, we show that exports react to the exchange rate between the country producing value added contained in exports and the country of final absorption for this value added. Three predictions follow: (i) a higher share of foreign value added in exports reduce the responsiveness of export volumes to exchange rate changes, (ii) a greater share of exports that returns as imports also reduce the responsiveness of export volumes and (iii) a higher share of inputs that are further reexported increase the responsiveness of exports to the trading partner's nominal effective exchange rate. Using a large origin-sector-destination level panel data set covering the period 1995-2009 and around 85\% of world GDP, we find strong empirical support for these predictions. We further show that some sectors in some countries can experience a decline in gross exports when their currency depreciates.
\end{abstract}

JEL Classification: F14, F40

Keywords: export elasticities, global value chains, currency unions, exchange rate passthrough

\footnotetext{
${ }^{a}$ Board of Governors of the Federal Reserve System, 2051 Constitution Avenue NW, Washington, DC. ${ }^{b}$ Sveriges Riksbank - Brunkebergstorg 11 - 10337 Stockholm.

${ }^{c}$ European Central Bank - Sonnemannstr. 20 - 60314 Frankfurt am Main.

${ }^{d}$ European Commission - Spastraat 2 - 1000 Brussel.

The views in this paper are solely the responsibility of the authors and should not necessarily be interpreted as reflecting the views of the Board of Governors of the Federal Reserve System, the Sveriges Riksbank, the European Central Bank or of any other person associated with these institutions.

We wish to thank Tamim Bayoumi, Rudolfs Bems, Philipp Hartmann, Michele Ruta and participants at internal European Central Bank, World Bank and Riksbank seminars, as well as seminar participants at the George Washington University Trade Workshop, the European Trade Study Group 2017, Toulouse School of Economics, the IMF Trade Seminar, the Central Bank of Poland and the Fall 2019 Midwest Macro Meetings for useful comments and suggestions.
} 


\section{Introduction}

The production processes for goods and services became increasingly fragmented across countries over the past few decades. The value-added ratio in global trade, defined as the domestic value-added in gross exports divided by total gross exports, fell from $87 \%$ in 1970 to $77 \%$ in 2009 (Johnson and Noguera, 2017). More comprehensive measures of global value chain (GVC) integration indicates that the expansion seems to have slowed since the 2008-2009 Great Recession (Timmer et al., 2016) but GVCs still account for a large share of global trade and more than half of gross exports of the euro area (ECB, 2017).

Participation in GVCs involves both "upstream" and "downstream" activities (Koopman et al., 2014). Firms are integrated "upstream" in the value chain when domestic inputs are replaced by imported inputs. Firms also have "downstream" linkages when they sell inputs that are used in further production processes. This means that some proportion of exports are re-exported further by the first trading partner, either to another final destination or back to the origin country. These changes in the organization of global production can affect how exports react to exchange rate changes and thus hamper external re-balancing (Leigh et al., 2017).

To date, most papers have evaluated the impact of upstream linkages on the response of export prices and volumes to exchange rate movements ("export elasticities" hereafter) (see for example, Amiti et al. 2014, Fauceglia et al. 2014, Ahmed et al. 2017, Arbatli and Hong 2016 and Georgiadis and Gräb 2019). In this paper, we consider both upstream and downstream linkages in GVCs and assess how they impact the export elasticities. We start by examining the question through the lens of a stylized partial equilibrium framework of international trade with cross-border production. From the model, we derive a set of predictions on the impact of integration in GVCs on the relationship between export volumes and exchange rate. We take advantage of precisely defined bilateral indices of GVC participation, based on the decomposition of Wang et al. (2013): foreign value added in exports that originate in destination countries with different currencies (foreign value added - $F V$ ), value added in exports that are re-exported by the trading partners (indirect value added - $I V$ ) and value added in exports that are re-imported at a later stage (re-imported domestic value added $R D V)$.

Our simple framework suggests that exports do not react to the direct exchange rate between the exporting and the importing countries of a given flow, but rather to the exchange rate between the country producing the value added contained in exports, and the country of 
final absorption for this value added. As a result, we show that both $F V$ and $R D V$ should decrease the elasticity of bilateral exports to exchange rates, whereas $I V$ should make trade flows sensitive to the trading partners nominal effective exchange rate.

To test the empirical relevance of the theoretical predictions, we use a large country-sectordestination-year panel data set from the World Input-Output tables that covers $85 \%$ of world GDP from 1995-2009 (Timmer et al., 2015). We then estimate the impact of the different GVC indices in shaping the export elasticities in an interacted panel fixed-effects regression. When deriving our GVC indices building on Wang et al. (2013), we take into account the possibility that the countries involved in the trade flow could share a common currency. This means that we take into account that some trade flows are within currency unions such as the Economic and Monetary Union of the European Union (EMU). Firms in countries within such areas share the same currency and movements in nominal exchange rates do not affect relative prices. When assessing the effect of GVCs on export elasticities, it is therefore imperative to also take into account that some trade flows are within currency unions.

The empirical results strongly corroborate the predictions from our simple theoretical model: (i) and similar to previous findings, a higher $F V$ (from a country with a different currency) reduces the responsiveness of export volumes to exchange rate movements. (ii) a higher $R D V$ also weakens the exchange rate responsiveness of export volumes, which highlights the importance of downstream linkages and (iii) a higher share of $I V$ increases the responsiveness of export volumes to the trading partner's nominal effective exchange rate. Interestingly, this last result implies that a country's exports can benefit from partner countries' depreciation.

With our point estimates and the observed distribution of GVC participation across originsector-destinations, we document that sectors with combined high shares of $F V$ and $R D V$ (above the $99^{\text {th }}$ percentile) might actually see their exports decline when their currency depreciates. This is not just an "exchange rate disconnect": it reverses the sign of the elasticity, as shown in Figure 1.

Our results confirm earlier studies on the impact of GVCs on export elasticities (for example Amiti et al. 2014 and Fauceglia et al. 2014). However we add a couple of crucial dimensions. We show that downstream linkages in GVCs are also important for the export reaction to exchange rates. Moreover, we acknowledge that, although the "global" part of the value chain has grown over time (Los et al., 2015), value chains are still in fact largely regional and often involve countries within large currency areas (Johnson and Noguera, 2012). This feature is taken into consideration when we construct our three measures of GVC integration that are suitable for assessing the impact of GVCs on exchange rate elasticities. In other words, from 
Figure 1: Effect of FV and RDV on the bilateral exchange rate elasticity

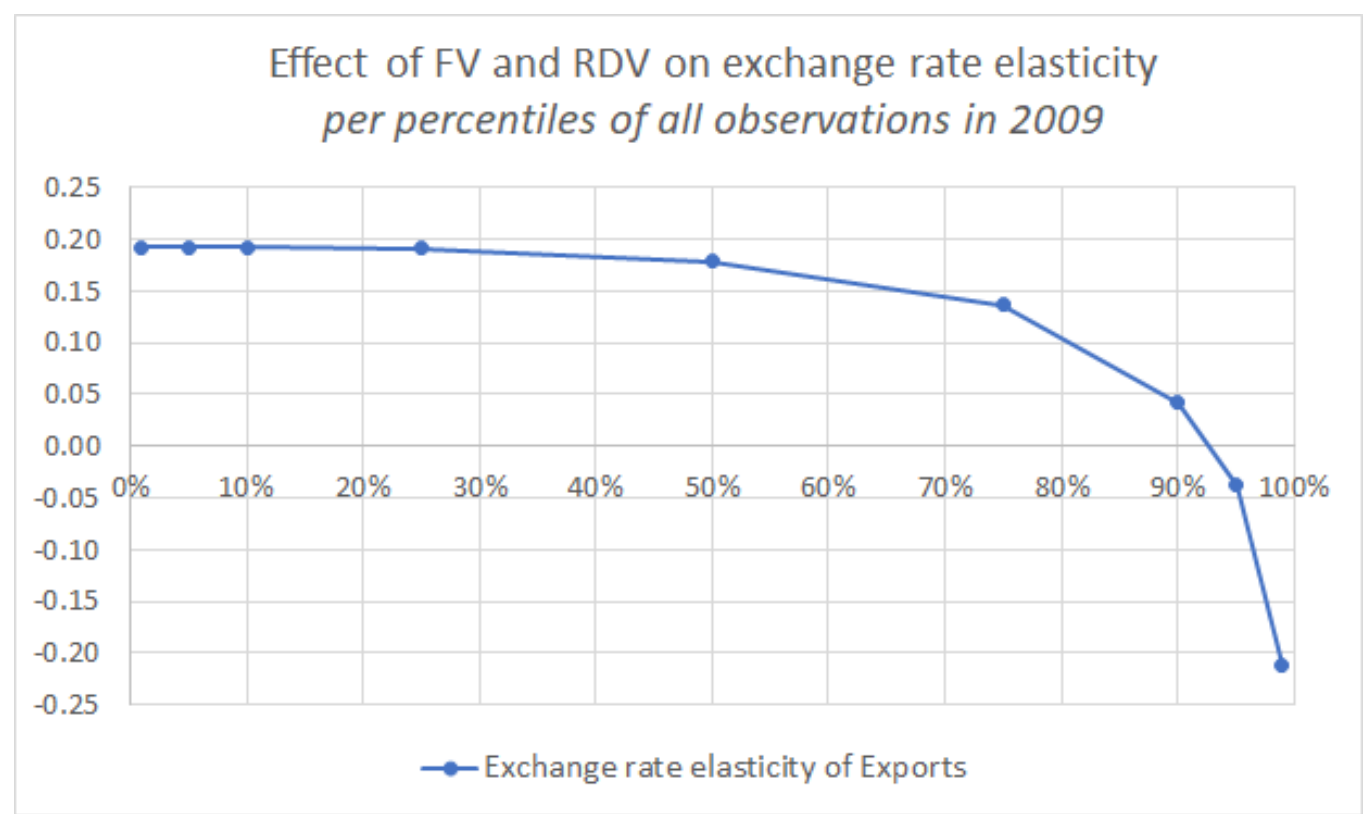

Source: World Input-Output tables (2013 release), Bank for International Settlements (BIS) and authors' calculations. Note: The horizontal axis corresponds to the different quantiles of GVC participation according to the weighted sum of FV and RDV indices, with weights corresponding to the marginal impact of the indices on export elasticities from the specification in column (4) of Table 3, including origin-sector-destination fixed effects and time dummies. The curve plots the corresponding elasticity of export volumes to exchange rates, using our point estimates for the effect of each index. For sectors with the highest level of both FV and RDV (at the far right of the graph), the corresponding elasticity is negative, meaning that a devaluation would decrease exports.

where value added is sourced and in which currency the trade is taking place and its final destination has implications for how much exports react to exchange rates.

The outline of the paper is as follows: Section 2 gives a brief description of the literature related to this paper. Section 3 outlines the theoretical framework and provides numerical predictions about the impact of global value chain participation on the exchange rate passthrough to export prices and the price elasticity of export volumes. Section 4 presents the main data sources, by outlining the difference between our currency-based global value chain indices and those of Wang et al. (2013). Section 5 introduces the econometric methodology and presents the results. Section 6 concludes.

\section{Related literature}

Currency movements are generally thought to affect trade prices and volumes. However, a secular expansion of cross-border production chains could reduce the competitiveness gains following a depreciation. This happens through an offsetting impact on the marginal costs of 
exporting firms or because value added crosses several borders and is subject to the impact of different exchange rates.

On the theoretical side, our work relates to papers modeling cross-border production and the associated consequences for trade elasticities, such as Yi (2003). More recently, Bems and Johnson (2017) examine how cross-border input linkages shape the response of demand for value added to international relative price changes. While they emphasize the role of relative elasticities in production versus consumption and condition their theoretical results on the value of model primitives, we take the direction of assuming Cobb-Douglas aggregation to derive more easily our predictions, which are then validated by our empirical exercise. ${ }^{1}$

By considering spending shares in the input-output matrix as constant in the short run (a natural consequence of our Cobb-Douglas assumptions), our work can be compared with Wang et al. (2013) and Koopman et al. (2014). Those papers pioneered the investigation of GVCs and created the decomposition of gross trade flows that is at the heart of the mechanisms we study. They derive the indices used in this paper (FV, RDV and IV) by manipulating inputoutput, value added and demand shares in a framework with many sectors and countries, and assuming that those coefficients are constant. Our model with Cobb-Douglas production and demand follows a similar logic and additionally provides new predictions regarding the association between GVCs and exchange rate pass-through, which are then validated using data from the World Input-Output Tables.

Empirically, Ahmed et al. (2017) find that participation in GVCs lowers the elasticity of manufacturing exports in OECD countries to the real effective exchange rate (REER) by 22 percent, on average, and by close to 30 percent for countries with the highest participation rates. Fauceglia et al. (2014) also explore how a decrease in relative prices of imported intermediate inputs may mitigate or even offset the negative effects of an exchange rate appreciation in Switzerland. Arbatli and Hong (2016) find that growing participation in global production chains and rising export complexity are important determinants of Singapore's export elasticities and Imbs and Mejean (2017) confirm that trade elasticities can differ because of the specialization of consumption and production, or because of international differences in sectorlevel trade elasticities. Moreover, the value of bilateral exchange rates might not be what matters for determining trade flows. Gopinath et al. (2020), for example, find that the US dollar is a dominant currency and important for determining global trade prices and volumes, more so than bilateral exchange rates.

Other factors that could reduce the responsiveness of exports to exchange rate movements

\footnotetext{
${ }^{1}$ We also share with Bems and Johnson (2017) the partial equilibrium nature of our theoretical exercise.
} 
relate to the use of pricing-to-market strategies among large exporters that tend to keep their export prices stable and absorb any variability in the exchange rate in their mark-ups. Based on Belgian firm-product-level data, Amiti et al. (2014) find that import intensity and market share are key determinants of the exchange rate pass-through to export prices. ${ }^{2}$

Although these studies have generally documented a lower exchange rate pass-through to export prices or reduced export elasticity to the exchange rate from increasing global value chain participation, they have not taken into consideration the full set of global production linkages (upstream and downstream), the origin of the import content in exports, nor the final destination of value added. Our contribution to this literature is that we consider precisely defined bilateral participation in both upstream and downstream value chains that capture all the important links. These indices allow us to distinguish between different types of GVC participation and how they affect export elasticities. Moreover, we construct bilateral measures of global value chain participation based on currencies, not countries, which improves the identification of the impact of global value chain participation on the export elasticities.

\section{Theoretical framework}

To motivate our empirical work and formalize our intuition, we propose a parsimonious static model of international trade with multiple countries. Our main goal is to illustrate through a series of examples several mechanisms through which participation in GVCs impacts both the exchange rate pass-through to export prices and the price elasticity of export volumes. In particular, we show that the effectiveness of currency changes in affecting exports depends on both the country of origin for the value added exported, as well as the country of final absorption for those exports. Hence, both upstream and downstream GVC participation shape the aggregate export response to an exchange rate shocks. We will then test our predictions in subsequent sections.

We make strong assumptions in order to streamline the analysis and derive predictions that can be brought to the data. For simplicity, our framework abstracts from other considerations such as markup fluctuations and strategic pricing, fixed exporting costs, various forms of price stickiness $^{3}$ or firms' usage of financial instruments to hedge agains currency movements.

\footnotetext{
${ }^{2}$ Besides global value chain integration and market power, other factors decrease prices' and volumes' sensitivity to exchange rate movements, such as: currency of invoicing and hedging decisions (Lyonnet et al., 2021), degree of openness to foreign trade (Campa and Gonzalez Minguez 2006), imported inputs' and exported goods' quality (Bernini and Tomasi 2015, Chen and Juvenal 2016 and Auer et al. 2018) or the presence of margins in the distribution sectors (Burstein et al. 2003 and Goldberg and Campa 2010).

${ }^{3}$ In our empirical analysis we investigate the effect of the dollar as dominant currency by adding the US dollar as additional explanatory variable in our export volumes and prices regressions.
} 
In a nutshell, our framework suggests that exports do not react to the direct exchange rate between the exporting and the importing countries of a given flow, but rather to the exchange rate between the country producing the value added contained in exports, and the country of final absorption for this value added. In particular, if a country $i$ exports final goods to country $j$ which also contains foreign value-added from country $k$, then the relevant exchange rate will be between $k$ and $j$. Moreover, if this export does not contain final goods but intermediate inputs that are further exported to country $l$, then the relevant exchange rate is between $k$ and $l$. In practice, note that export flows contain a mix of value added from home and foreign sources, and these different components are partly absorbed by the direct partner and partly by countries further down in the production chain.

\subsection{Production}

Consider an economy with $N$ countries indexed by $k$. In each country, there is a single sector with a representative firm producing with domestic labor and imported inputs according to a Cobb-Douglas technology:

$$
Y_{k}=\ell_{k}^{\gamma_{k}} \times \prod_{k^{\prime}=1}^{N} m_{k, k^{\prime}}^{\alpha_{k, k^{\prime}}} \quad \text { with } \quad \gamma_{k}+\sum_{k^{\prime}=1}^{N} \alpha_{k, k^{\prime}}=1
$$

where $\gamma_{k}$ is the labor share in production in country $k$, while $\alpha_{k, k^{\prime}}$ is the share of output from country $k^{\prime}$ in the total production of country $k$. Note that $Y_{k}$ is the gross output produced by country $k$, which is not equal to value added. $\varepsilon_{i, j}$ is the exchange rate faced by country $i$ vis-à-vis country $j$, that is, the units of country $i$ currency per unit of country $j$ currency. ${ }^{4}$ Firms are perfectly competitive, price at marginal cost and buy all their inputs in their domestic currency. ${ }^{5}$ Our assumption of zero markup could be replaced by constant markups without changing any of our insights. In the absence of trade costs and taxes, standard cost minimization in each country leads to the following pricing system:

$$
p_{k}=c_{k} \times w_{k}^{\gamma_{k}} \times \prod_{k^{\prime}=1}^{N}\left(\varepsilon_{k, k^{\prime}} p_{k^{\prime}}\right)^{\alpha_{k, k^{\prime}}} \quad \text { for all } k
$$

\footnotetext{
${ }^{4}$ One should keep in mind that with this definition, a depreciation of country $i$ 's currency (compared with the one of country $j$ ) corresponds to an increase in $\varepsilon_{i, j}$ and a decrease in $\varepsilon_{j, i}$

${ }^{5}$ In a static environment with perfect competition where prices are equal to marginal costs, firms' pricing strategy is not affected by the currency in which such price is set. The equations presented here can be interpreted as if firms set the price in their own currency (so called "Producer Currency Pricing").
} 
With $c_{k}$ a constant depending only on parameters. ${ }^{6}$ We can then take the log and introduce $k_{k}=\log \left(c_{k}\right)$ and $\Omega$ the cross-country input-output matrix of the economy (with $\Omega_{i, j}=\alpha_{i, j}$ ). Country-specific prices are then the solution of:

$$
\left(\begin{array}{c}
\log \left(p_{1}\right) \\
\vdots \\
\log \left(p_{N}\right)
\end{array}\right)=\left(\mathcal{I}_{N}-\Omega\right)^{-1}\left[\left(\begin{array}{c}
k_{1}+\left(\gamma_{1}\right) \log \left(w_{1}\right) \\
\vdots \\
k_{N}+\left(\gamma_{N}\right) \log \left(w_{N}\right)
\end{array}\right)+\Omega \circ \log (\mathbf{E})\left(\begin{array}{c}
1 \\
\vdots \\
1
\end{array}\right)\right]
$$

where $\mathbf{E}$ is an $N$-by- $N$ matrix of nominal exchange rate defined by $E_{i, j}=\varepsilon_{i, j}$, the symbol $\circ$ represents the element-wise (Hadamard) product and the log operator on $\mathbf{E}$ is applied elementwise. As usual, the matrix $\left(I_{N}-\Omega\right)^{-1}$ is the Leontief inverse and captures all direct and indirect input-output linkages and naturally appears in the pricing equation. It is worth noting here that the price of a firm in any country is a function of the price of all its direct and indirect suppliers and all associated exchange rates. If country 1 exports inputs to country 2 that are used in production and re-exported to country 3 , then the price level in country 3 is a function of the exchange rate with its direct suppliers $\varepsilon_{3,2}$ as well as the exchange rate relative to upstream production steps such as $\varepsilon_{2,1}$.

As discussed extensively in the literature, gross trade data can be deeply misleading in the presence of complex production networks. With global production patterns, it is becoming increasingly important to use value-added flows. We illustrate this phenomenon by considering a simple case with only three countries and a specific input-output structure as follows:

$$
\Omega=\left(\begin{array}{ccc}
0 & \alpha_{1,2} & \alpha_{1,3} \\
\alpha_{2,1} & 0 & \alpha_{2,3} \\
\alpha_{3,1} & \alpha_{3,2} & 0
\end{array}\right)
$$

In such a case, it is useful to write a closed form solution for $\log \left(p_{1}\right)$ to gain some intuition for the impact of different elements on firms' pricing behavior:

$$
\begin{aligned}
\log \left(p_{1}\right)=\frac{1}{\operatorname{det}\left(\mathcal{I}_{3}-\Omega\right)} & {\left[\left(1-\alpha_{3,2} \alpha_{2,3}\right)\left(k_{1}+\gamma_{1} \log \left(w_{1}\right)+\alpha_{1,2} \log \left(\varepsilon_{1,2}\right)+\alpha_{1,3} \log \left(\varepsilon_{1,3}\right)\right)\right.} \\
& +\left(\alpha_{1,2}+\alpha_{1,3} \alpha_{3,2}\right)\left(k_{2}+\gamma_{2} \log \left(w_{2}\right)+\alpha_{2,1} \log \left(\varepsilon_{2,1}\right)+\alpha_{2,3} \log \left(\varepsilon_{2,3}\right)\right) \\
& \left.+\left(\alpha_{1,3}+\alpha_{1,2} \alpha_{2,3}\right)\left(k_{3}+\gamma_{3} \log \left(w_{3}\right)+\alpha_{3,1} \log \left(\varepsilon_{3,1}\right)+\alpha_{3,2} \log \left(\varepsilon_{3,2}\right)\right)\right]
\end{aligned}
$$

\footnotetext{
${ }^{6} c_{k}$ is defined as: $c_{k}=\gamma_{k}^{-\gamma_{k}} \prod_{k^{\prime}} \alpha_{k, k^{\prime}}^{-\alpha_{k}}$. Assuming that firms charge a constant markup $\mu$ would only add a term in the expression of $c_{k}$ without modifying subsequent analysis.
} 
Note that this expression of prices is independent of the demand side of the economy, which will be described in the next section. Equation (3) allows us to compute the exchange rate pass-through to export prices. To do so, one must specify the exact currency movements for all country pairs. To gain intuition, we look at a very simple case and consider the case of depreciation in country 1 vis-à-vis the other two countries. We assume that both countries do not alter the value of their own currency. In such a case, we have:

$$
\left\{\begin{aligned}
1 & =\Delta \log \left(\varepsilon_{1,2}\right)=\Delta \log \left(\varepsilon_{1,3}\right) \\
-1 & =\Delta \log \left(\varepsilon_{2,1}\right)=\Delta \log \left(\varepsilon_{3,1}\right) \\
0 & =\Delta \log \left(\varepsilon_{2,3}\right)=\Delta \log \left(\varepsilon_{3,2}\right)
\end{aligned}\right.
$$

Generally, a depreciation of country 1's currency could also impact the wage rates in all countries. ${ }^{7}$ For simplicity, we abstract from these general equilibrium effects here. Using the above result, we can compute the elasticity on country 1 price (in its domestic currency) with respect to a one percent depreciation of its own currency, everything else being constant with $\lambda=\operatorname{det}\left(I_{3}-\Omega\right)^{-1}$ :

$$
\begin{aligned}
\left.\Delta \log \left(p_{1}\right)\right|_{1 \% \text { depreciation in } 1=} & \lambda\left[\left(\alpha_{1,2}+\alpha_{1,3}-\left(\alpha_{1,2} \alpha_{2,1}+\alpha_{1,3} \alpha_{3,1}\right)\right.\right. \\
& \left.-\alpha_{1,2}\left(\alpha_{2,3} \alpha_{3,1}+\alpha_{3,2} \alpha_{2,3}\right)-\alpha_{1,3}\left(\alpha_{3,2} \alpha_{2,1}+\alpha_{3,2} \alpha_{2,3}\right)\right]
\end{aligned}
$$

Equation (5) provides intuitions regarding the role of GVCs for the exchange rate passthrough. As a first order effect, a depreciation of country 1's currency makes its imports relatively more expensive, which increases its price (in its own currency, but obviously not in foreign currency) as shown by the first term in the bracket, $\alpha_{1,2}+\alpha_{1,3}$. Such an effect has been studied extensively and has been tested in the data for example in Amiti et al. (2014).

However, the importance of imported inputs for the pass-through is mitigated by the fact that some imported inputs are not entirely produced abroad, but contain domestic value added that returns home as imports. Such value added comes from direct linkages (second term of the above equation, $\left.\left(\alpha_{1,2} \alpha_{2,1}+\alpha_{1,3} \alpha_{3,1}\right)\right)$ or indirectly through third country effects (third and fourth term). These terms reduce the first order increase because of the direct linkages. This discussion illustrate the importance of decomposing gross trade flows into value-added components.

\footnotetext{
${ }^{7}$ The consequence of a depreciation on the labour market can be twofold: if there are some unemployed resources, depreciation can increase employment and output by stimulating foreign demand. If factors of production are fixed, it can increase wages. See Krugman and Taylor (1978) for a theoretical discussion of the possible contractionary effects of depreciation.
} 


\subsection{Demand}

We now return to the general case with many countries. Goods produced in any country can be sold to domestic and foreign buyers as final good or as inputs. Demand stemming from consumers is derived from a reduced form utility function defined by:

$$
C_{k}=\prod_{k^{\prime}}^{N} y_{k, k^{\prime}}^{\beta_{k, k^{\prime}}} \quad \text { with } \sum_{k^{\prime}}^{N} \beta_{k, k^{\prime}}=1
$$

where $\beta_{k, k^{\prime}}$ captures the share of country $k^{\prime}$ in final consumption of country $k$ and $y_{k, k^{\prime}}$ is the quantity of good produced in $k^{\prime}$ consumed in $k$.

In order to simplify the analysis and to abstain from general equilibrium effects, we assume an exogenous mass $L_{k}$ of agents in country $k$, all employed and earning an exogenous wage rate $w_{k}$. In what follows, we assume that the nominal wage is exogenously fixed and is not affected by exchange rate movements. It is important to note the partial equilibrium nature of this assumption: The wage is not determined by market clearing in the labour market and we do not model what happens to workers not employed by the domestic firm. ${ }^{8}$ The Cobb-Douglas nature of aggregate preferences implies that:

$$
\left\{\varepsilon_{k^{\prime}, k} p_{k} y_{k^{\prime}, k}=\beta_{k^{\prime}, k} w_{k^{\prime}} L_{k^{\prime}}, \quad \forall k, k^{\prime}\right.
$$

Moreover, demand schedules coming from foreign firms are simply

$$
\left\{\varepsilon_{k^{\prime}, k} p_{k} \cdot m_{k^{\prime}, k}=\alpha_{k^{\prime}, k} p_{k^{\prime}} Y_{k^{\prime}}, \quad \forall k, k^{\prime}\right.
$$

As a reminder, in the equations above, the exchange rate $\varepsilon_{k^{\prime}, k}$ transforms country $k$ currency into country $k^{\prime}$ 's. When country $k$ devalues its currency vis-à-vis $k^{\prime}, \varepsilon_{k^{\prime}, k}$ decreases so that the price of $k$-produced good sold in $k^{\prime}$ 's currency decreases, which leads to higher quantities exported.

\subsection{Market Clearing}

Using equations (6) and (7) and the fact that $\varepsilon_{i, j}=1 / \varepsilon_{j, i}$, we can equate production to the sum of sales across all agents. Market clearing conditions can be written, in nominal terms for

\footnotetext{
${ }^{8}$ A simple micro-foundation of this would simply be to model an "outside good" sector employing labour only and which would be freely traded across countries.
} 
simplicity, as:

$$
\left(\begin{array}{c}
p_{1} Y_{1} \\
\vdots \\
p_{N} Y_{N}
\end{array}\right)=\left(\mathcal{I}_{N}-\Omega^{T} \circ \mathbf{E}\right)^{-1} \cdot\left(\mathbf{B}^{T} \circ \mathbf{E}\right) \cdot\left(\begin{array}{c}
w_{1} L_{1} \\
\vdots \\
w_{N} L_{N}
\end{array}\right)
$$

where $\mathbf{B}$ is a N-by-N matrix grouping the shares $\beta_{i, j}$. For notational purposes, let us denote $\mathbf{T}=\left(\mathcal{I}_{N}-\Omega^{T} \circ \mathbf{E}\right)^{-1}$.

Compared with the pricing system (2), it is interesting to note that in the revenue system (8) the input-output matrix $\Omega$ is transposed, which stems from the fact that the revenue of a given firm depends on the revenue of its customers (downstream linkages), whereas prices depend solely on a firm's direct and indirect suppliers (upstream linkages). ${ }^{9}$ For given wages, the (partial) equilibrium is then defined by optimality of pricing system (2) and market clearing conditions system (8).

\subsection{Decomposition of gross exports}

This section elaborates on the consequences of a depreciation of country 1's currency vis-à-vis other currencies and how global value chain participation affects the export elasticities. We start by formally defining three indices of global value chain participation.

Our model shares the same structure as Koopman et al. (2014) and Wang et al. (2013), with Cobb-Douglas aggregation for both production and demand sides. Following these papers, we define three indices which are presented schematically in Figure 2. The general idea underlying this decomposition is to separate, in the expression of total trade flows, the value added embedded in exports by both origin and destination of final absorption. As pointed out above, doing so requires knowledge of all input-output as well as demand linkages.

The $F V$ index measures the share of foreign value-added in exports and is a purely "backward-looking" indicator in the sense that it does not depend on the country of final absorption of the value added. It is related to the "import content of export" used in other papers such as Amiti et al. (2014) but focuses on the value added flows rather than gross flows. It is constructed based on the Leontief inverse.

The $I V$ index measures the domestic value added that is exported and used by the direct trading partner for the production of their own exports to other countries. ${ }^{10}$

The third index, labeled $R D V$, captures the domestic value added exported abroad and re-imported back home where it is finally absorbed. Such an index is particularly interesting

\footnotetext{
${ }^{9}$ See for example Acemoglu et al. (2016) for a discussion of this.

${ }^{10}$ In the GVC literature, $F V$ and $I V$ are also considered measures of backward and forward participation in GVC, respectively.
} 
Figure 2: Decomposition of nominal export flows

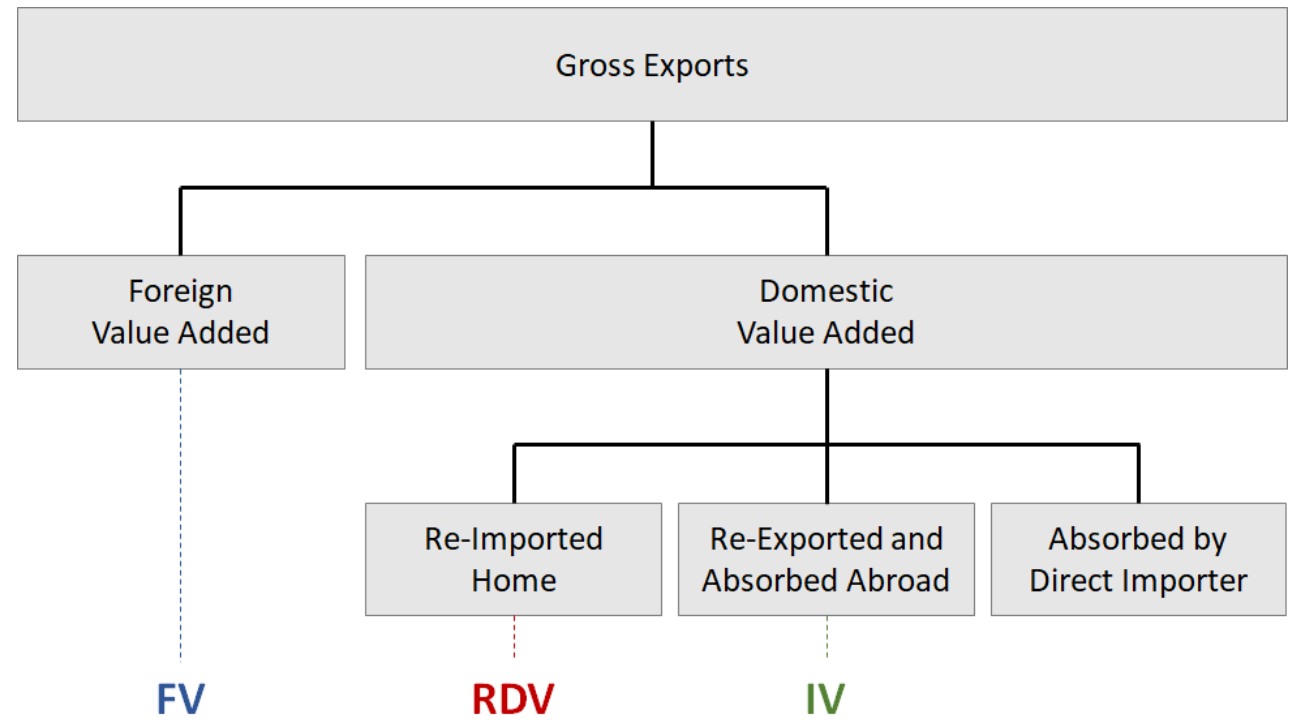

when studying the impact of currency movements on trade elasticities since it measures the value added in exports that is driven by domestic demand of the exporting country.

Following the decomposition proposed in Wang et al. (2013), the analytical expression for gross export is very similar to previous papers. In particular, following the exact same computational steps adapted to our framework, gross exports from country 1 to country 2 , $E_{1 \rightarrow 2}$, can be expressed as:

$$
\begin{aligned}
E_{1 \rightarrow 2} & =\underbrace{v_{1} T_{1,1} \varepsilon_{1,2} \beta_{2,1} w_{2} L_{2}+v_{1} T_{1,2} \beta_{2,2} w_{2} L_{2}}_{\text {Absorbed by direct partner }} \\
& +\underbrace{v_{1} \sum_{k \neq 1,2} T_{1,2} \varepsilon_{2, k} \beta_{k, 2} w_{k} L_{k}}_{\mathrm{IV}} \\
& +\underbrace{v_{1} T_{1,2} \varepsilon_{2,1} \beta_{1,2} w_{1} L_{1}+v_{1} T_{1,2} \varepsilon_{2,1} \alpha_{1,2} \frac{1}{1-\alpha_{1,1}} \beta_{1,1} w_{1} L_{1}}_{\mathrm{RDV}} \\
& +\underbrace{\sum_{k \neq 1} v_{k} T_{k, 1} \varepsilon_{1,2} \beta_{2,1} w_{2} L_{2}+\sum_{k \neq 1} v_{k} T_{k, 1} \varepsilon_{1,2} \alpha_{2,1} \frac{1}{1-\alpha_{2,2}} \beta_{2,2} w_{2} L_{2}}_{\text {Fouble counting }}
\end{aligned}
$$

where $T_{i, j}$ are elements of the matrix $\mathbf{T}$ defined above and $v_{i}$ is the value added share of gross output in country $i$, which is simply equal to the share of labour in total costs and is defined by $v_{i}=1-\sum_{k=1}^{N} \alpha_{i, k}=\gamma_{i} \cdot{ }^{11}$ Moreover, $E_{j \rightarrow *}$ represents total gross exports from country $j$,

\footnotetext{
${ }^{11}$ As shown in Koopman et al. (2014), one can decompose gross nominal trade flows into value added com-
} 
irrespective of the destination country. Based on this expression, one can construct the value of all GVC indices for every country-pair and year using data on the value of input-output shares (the $\alpha \mathrm{s}$ ), demand shares (the $\beta \mathrm{s}$ ), aggregate demand and bilateral export flows. We will construct these indices in subsequent sections using data from the World Input-Output Database.

\subsection{Illustrative examples}

Using the equilibrium structure described above, we now specify examples of network structures in order to emphasize the role of both upstream and downstream linkages in shaping the export elasticities and to derive qualitative predictions for the role of each of the three indices of GVC participation $(F V, R D V$, and $I V)$.

\subsubsection{Role of upstream linkages}

Let us consider the production structure depicted in Figure 3 where country 1 only exports final goods to country 2 and imports intermediate inputs from both country 2 and 3 . Because country 1 uses foreign value added in its export, we have $F V \neq 0$. But since country 1 does not export any intermediate inputs, all exports are directly absorbed by the associated direct partner and by construction we have $R D V=0$ and $I V=0$.

Figure 3: GVC with only "upstream" linkages

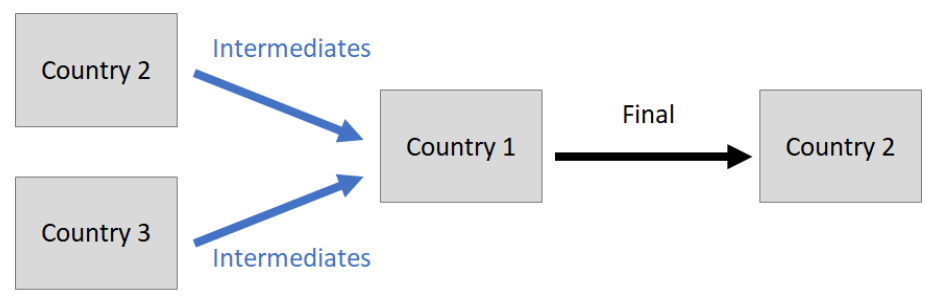

The associated model parameters are:

$$
\Omega=\left(\begin{array}{ccc}
0 & \alpha_{1,2} & \alpha_{1,3} \\
0 & 0 & 0 \\
0 & 0 & 0
\end{array}\right) \quad \text { and } \quad \mathbf{B}=\left(\begin{array}{ccc}
\beta_{1,1} & 0 & 0 \\
\beta_{2,1} & \beta_{2,2} & 0 \\
0 & 0 & \beta_{3,3}
\end{array}\right)
$$

Using (6), nominal exports from 1 to 2 in country 1's currency can be expressed as $E_{1 \rightarrow 2}=$ ponent by using the following equation:

$$
\sum_{k=1}^{N} v_{k} T_{k, i}=1 \quad \forall i
$$


$\varepsilon_{1,2} \beta_{2,1} w_{2} L_{2}$, which can be log-differentiated as:

$$
d \log \left(E_{1 \rightarrow 2}\right)=d \varepsilon_{1,2}
$$

The above expression is a natural consequences of our Cobb-Douglas assumption: regardless of currency values, a fraction $\beta_{2,1}$ of country 2's total spending in country 2 is allocated to final goods coming from country 1 . Hence, a depreciation in country 1 has no impact on final demand in country 2's currency but translates into a one-for-one increase in export values labeled in country 1's currency. Assuming constant wages in our partial equilibrium framework, we can get a simple expression for the exchange rate pass-through. ${ }^{12}$

$$
d \log \left(p_{1}\right)=\alpha_{1,2} d \varepsilon_{1,2}+\alpha_{1,3} d \varepsilon_{1,3}
$$

Using equations (10) and (11), the impact of currency changes on real exports from country 1 to country 2 is simply:

$$
d \log \left(y_{2,1}\right)=\left(1-\alpha_{1,2}\right) d \varepsilon_{1,2}-\alpha_{1,3} d \varepsilon_{1,3}
$$

When country 1 devalues its currency vis-à-vis $2, \varepsilon_{1,2}$ increases. As illustrated by (12), the associated change in real exports $\log \left(y_{2,1}\right)$ is impacted by the foreign value-added embedded in exports. The first term on the right hand side, governed by $\alpha_{1,2}$, relates to the foreign value added coming from the destination country, which unambiguously decreases the elasticity of real exports to exchange rate. The second term relates to value added coming from a third country. Such a linkage is a priori ambiguous since it depends on the relative currency values between 1 and 3 . The direction of this channel then depends on the correlation between $\varepsilon_{1,2}$ and $\varepsilon_{1,3}$. Overall, from this simple case we can infer that the share of foreign value added in exports coming from the direct partner's country reduces the exchange rate pass-through to export prices and export volumes.

\subsubsection{Role of downstream linkages}

While the literature has extensively studied how imported inputs can reduce the reactivity of exports to exchange rate movements, our model also allows us to derive prediction for the role of downstream linkages. In order to illustrate this in the simplest form, we consider the supply chain presented in Figure 4: In such a case, country 1 does not import any intermediate input and hence is characterized by $F V=0$. However, it exports intermediate inputs that are used

\footnotetext{
${ }^{12}$ Note that one can use (2) to get the proportional change in country 1's price, $p_{1}$, following movements in currency values.
} 
Figure 4: GVC with no "upstream" linkages

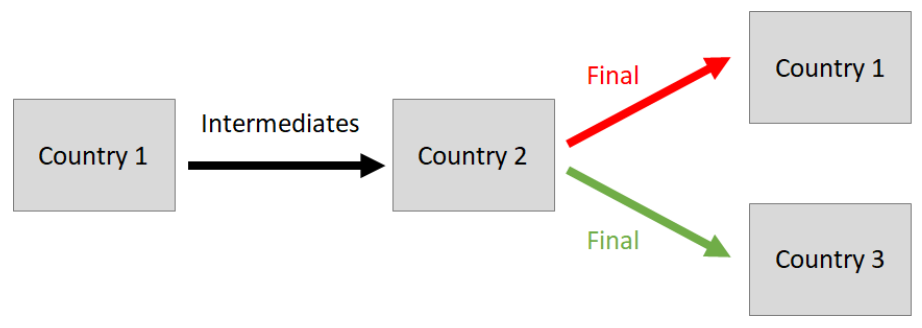

for further exports to country 3 as well as back in country 1 (so that $I V \neq 0$ and $R D V \neq 0$ respectively). The associated model parameters are:

$$
\Omega=\left(\begin{array}{ccc}
\alpha_{1,1} & 0 & 0 \\
\alpha_{2,1} & \alpha_{2,2} & 0 \\
0 & 0 & \alpha_{3,3}
\end{array}\right) \quad \text { and } \quad \mathbf{B}=\left(\begin{array}{ccc}
\beta_{1,1} & \beta_{1,2} & 0 \\
0 & \beta_{2,2} & 0 \\
0 & \beta_{3,2} & \beta_{3,3}
\end{array}\right)
$$

Using (8), we can derive a closed-form expression of nominal output in all countries. Then, with (7), we get a closed-form expression for nominal exports from country 1 to country 2 in country 1's currency:

$$
E_{1 \rightarrow 2}=\underbrace{\frac{\alpha_{2,1} \beta_{1,2}}{1-\alpha_{2,2}} w_{1} L_{1}}_{\mathbf{1}}+\underbrace{\varepsilon_{1,2} \frac{\alpha_{2,1} \beta_{2,2}}{1-\alpha_{2,2}} w_{2} L_{2}}_{\mathbf{2}}+\underbrace{\varepsilon_{1,3} \frac{\alpha_{2,1} \beta_{3,2}}{1-\alpha_{2,2} w_{3} L_{3}}}_{\mathbf{3}}
$$

When country 1 devalues its currency vis-à-vis country $2, \varepsilon_{1,2}$ increases and the associated consequences on $E_{1 \rightarrow 2}$ are strongly impacted by participation in GVCs. From looking at the decomposition in (13), we can see that the first term on the right-hand side, which is governed by the $R D V$ index, is not affected at all by the depreciation. Intuitively, this is the case because the final demand driving this part of exports is located in country 1 and is labeled in country 1's currency. As a result, a depreciation of country 1's currency is simply ineffective in attracting additional demand: The larger this term, the lower the sensitivity of exports to depreciation.

The second term in (13) increases exactly one-for-one with $\varepsilon_{1,2}$. This part corresponds to the share of exports from 1 to 2 that is ultimately absorbed in country 2. Its proportional change is naturally equal to the price elasticity of demand, which is equal to one with our Cobb-Douglas assumption.

Finally, the third term is ambiguous and depends on fluctuations of country 1's currency vis-à-vis 3. This last term, which is governed by the $I V$ index, corresponds to exports from country 1 to country 2 that are ultimately absorbed in country 3. Hence, the final demand 
driving this part of the exports is labeled in country 3's currency, and the exchange rate that matters for this flow relates the country of origin (country 1) to the country of absorption (country 3), leapfrogging any intermediate production step. This result of course crucially depends on the Cobb-Douglas assumption in production. ${ }^{13}$ Note that since country 1 does not import any intermediate inputs, its domestic price is independent of the relative value of its currency so that we have $d \log \left(p_{1}\right)=0$. It then follows that the proportional change in real exports is exactly equal to the proportional change in nominal exports:

$$
d \log \left(m_{2,1}\right)=d \log \left(E_{1 \rightarrow 2}\right)-d \log \left(p_{1}\right)=d \log \left(E_{1 \rightarrow 2}\right)
$$

\subsection{Summary of testable predictions}

The examples presented above emphasize that exports can be broken down into value added pieces. Each piece then reacts to the exchange rate between the country where the value added was initially produced and the country of final absorption. This logic gives rise to three testable predictions which we explicit here and formally test in subsequent sections.

1. Upstream integration in GVCs, as measured by foreign value added embedded in export and captured by the $F V$ index, is associated with a decrease in the elasticity of exports to exchange rates.

2. Downstream integration, which refers to situations when the direct partner of an export flow is not the country of final absorption, also matters. In the case of $R D V$-type participation, the country of final absorption is the same as (or shares the same currency as) the exporting country. Hence, the associated export flow is independent of the direct exchange rate, which means that an increase in $R D V$ reduces the elasticity of exports to exchange rate.

3. For $I V$-type participation, the final country of absorption is neither the exporting country nor the direct partner. These trade flows are sensitive to the exchange rate vis-à-vis countries further downstream in the production chain.

The simplicity of our predictions follows from our strong assumption, in particular CobbDouglas production and demand aggregates, flexible prices and constant markups. ${ }^{14}$ Recall

\footnotetext{
${ }^{13}$ Indeed, if inputs were perfect substitutes in the production function of country 2 , then any appreciation of country 1's currency vis-à-vis country 2 would result in a collapse in demand from country 1's inputs, irrespective of the country of final absorption. While Cobb-Douglas is a strong assumption, it allows us to derive simple predictions that are then tested in the data. In section 5, we find significant empirical support for those predictions.

${ }^{14}$ As mentioned above, having no markup or constant markups does not change our predictions.
} 
that our main goal was to propose a framework that is simple enough to provide intuition, yet detailed enough to guide our empirical investigations. We now formally test these predictions.

\section{Data}

Testing the implications from the previous section requires a detailed data set that captures all the important upstream and downstream links embedded in GVCs. We utilize mainly two sources: (i) the World Input-Output Tables (WIOD) and (ii) a sectoral panel data set from the Socio-Economic Accounts (SEA). ${ }^{15}$ These tables contain annual global input-output information for 35 sectors, comprising primary, durable and non-durable manufacturing as well as services sectors, including financial intermediation and covers around $85 \%$ of world GDP.

The tables are available for 40 countries of which a majority are in the European Union, but also include countries in North America, South America, and Asia, as well as rest of the world (constructed as one economy) from 1995 to 2011. These tables are available in current (to 2011) and in previous years prices (to 2009). ${ }^{16}$ Therefore, for each year a full country-sector input-output matrix of the dimension $1,435 \times 1,435$ is available and allows for the analysis of bilateral supply and use relationships between a sector in a specific country and all other sectors in the 39 countries. ${ }^{17}$

The Socio-Economic Accounts of the WIOD contain a multi-country panel of sector data on, for example, gross output and value added in current prices and previous years prices. The bilateral nominal exchange rates are provided by the WIOD, whereas we obtain nominal effective exchange rates from the Bank for International Settlements (BIS). Together, these sources enable us to construct bilateral trade flows, export prices, exchange rates and indices of global value chain participation. To alleviate issues regarding possible endogeneity or reverse causality of export volumes and bilateral exchange rates at the aggregate level, our empirical analysis will be conducted at the sector-level. Because each sector is small compared to the aggregate economy of a country, export prices and volumes at such a disaggregated level is less likely to directly impact bilateral exchange rates at the aggregate level.

Obtaining real bilateral exports flows between a sector $s$ and its destination market $d$ from the WIOD is straightforward: We calculate the gross nominal flows (both of final and intermediate products) from sector $s$ in country $o$ to other countries $d$ (where $o \neq d$ ). Sector-

\footnotetext{
${ }^{15}$ See Timmer et al. (2015) and www.wiod.org

${ }^{16}$ The 2016 release of the World Input-Output Tables contains information for 56 sectors in 43 countries annually from 2000 to 2014 .

${ }^{17}$ In the rest of the empirical analysis, we drop observations relating to "Private households with employed persons" with largely zero trade flows and winsorize the sample at the $99^{\text {th }}$ percentile.
} 
level export prices to a particular destination are computed by dividing the global input-output tables in current prices with the same tables in previous year's prices for each year. Since the WIOD is expressed in U.S. dollars, we convert them to local currencies (country o's) with bilateral exchange rates. We consider export prices from sector $s$ in country $o$ to destination market $d$ (recall that $o \neq d$ so intra-country prices are not included), and we use them to deflate the corresponding gross nominal export flows to obtain real values. Following the theoretical model, these prices will be expressed in the destination markets' (d's) currency.

\subsection{Currency- and country-based indices of GVCs}

Our three main indices $(F V, I V$, and $R D V)$ of GVC participation follow the decomposition of sectoral gross exports developed by Wang et al. (2013). However, these measures need to be adapted to be comparable to our predictions from Section 3. Recall that in the theoretical model, each country has its own currency. Since reality is more complex and countries participate in currency unions (such as the EMU) or have currency pegs, we construct indices of GVC participation that are based on currencies instead of countries. This is important, because it is arguably only those trade flows in GVCs that vary with the bilateral exchange rates that will impact the trade elasticities.

To elucidate the general concept of our currency-based indices, Figure 5 provides a graphical representation. Starting with the first index, $F V$ : this measure includes all (value-added) imports of an origin-sector from a destination that are used to produce exports to the same destination. If the destination market $d$ has the same currency as the origin o (i.e. $\varepsilon_{o, d}=1$ ), the import content will be nil and $F V_{o \rightarrow d}=0$.

Take as an example a German firm that exports its products to the United States. Increasing the value added imported from the United States is expected to reduce the elasticity of German firm's export volumes to the EUR/USD exchange rate. Inputs sourced by the German firm from countries with the same currency as Germany (such as Spain) should have no impact on the bilateral export elasticities to the United States. Moreover, imported inputs from countries with different currencies than the EUR or USD would have an ambiguous impact on the elasticities and would depend on the relative exchange rate movements of the three currencies.

Our second index in panel (b), $I V$, differs from the corresponding country-based one in that it takes into consideration the currency of the country that re-exports the product. To illustrate this, we continue with the example of the German firm: It sells components to an assembly plant in Mexico, which are processed and later re-exported to the United States as a finished product. In this case, our $I V$ measure and the country-based index coincide. However, 
Figure 5: Stylized example of GVC participation indices

(a) FV index

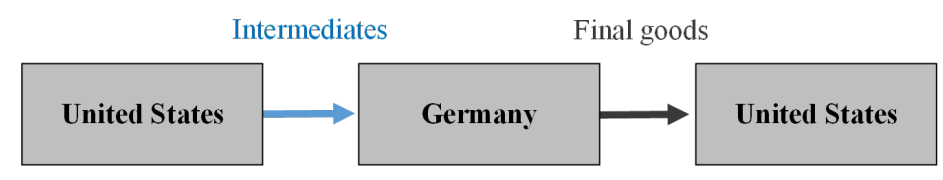

(b) IV and RDV index

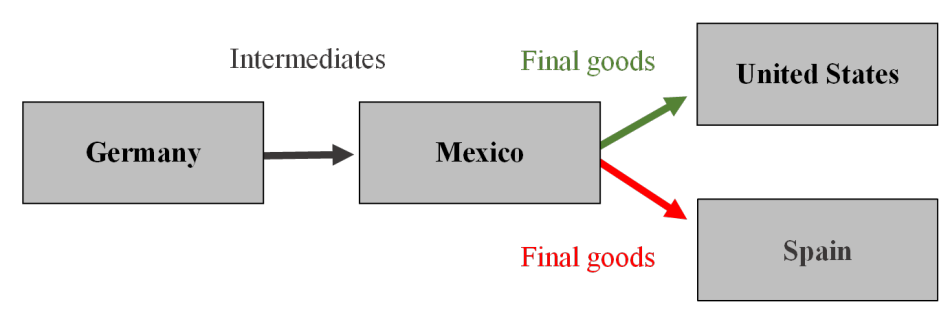

if all countries (origin, assembler, and final destination) are within a currency area such as the EMU, the $I V$ measure would not be counted at all, since the transactions are made in the same currency (without any currency effects).

If the final destination of exports is within the same currency area as Germany (here Spain) as in panel (b), we would consider that as domestic value added that returns "home" and would be counted as our third index in panel (c), $R D V \cdot{ }^{18}$ All value added that goes through a trading partner with a different currency but returns to a country with the same currency as the origin, will thus be counted as "returned domestic value added," or $R D V$. In the country-based decomposition, this trade flow would instead be counted as $I V$.

\subsection{Comparing the different indices}

Table 1 shows averages, max and minimums for our measures based on currencies and those based on countries (as in Wang et al. 2013), computed over all country-sector-destination pairs

\footnotetext{
${ }^{18}$ In the country-based decomposition of gross exports, $R D V$ flows would only be counted as exports of intermediate inputs that are re-imported into the same country.
} 
in 2005, which is a midpoint in the data. As expected, the currency-based $I V$ is smaller than the one based on countries on average, whereas $R D V$ is larger. By construction, some exports in $I V$ will end up in $R D V$ when we recompute the measures on currencies instead of countries. ${ }^{19}$ The index values are also different across the distribution (see Figure 6). Both the $F V$ and the $I V$ measure based on countries is larger than measures based on currencies. Conversely, the $R D V$ measure based on currencies in the $95^{\text {th }}$ percentile is much higher (almost $16 \%$ at the $99^{t h}$ percentile, compared with just over $6 \%$ for measures based on countries).

Table 1: Summary statistics of FV, IV and RDV in 2005

\begin{tabular}{lcccc}
\hline & & FV & IV & RDV \\
& & & & \\
\hline Based on currencies & Average & $0.3 \%$ & $16.0 \%$ & $1.4 \%$ \\
& Max & $44.7 \%$ & $93.8 \%$ & $38.5 \%$ \\
& Min & $0.0 \%$ & $0.0 \%$ & $0.0 \%$ \\
Based on countries & Average & $0.4 \%$ & $18.9 \%$ & $0.4 \%$ \\
& Max & $44.7 \%$ & $93.8 \%$ & $33.0 \%$ \\
& Min & $0.0 \%$ & $0.0 \%$ & $0.0 \%$ \\
\hline
\end{tabular}

Figure 6: Currency- and country-based GVC participation indices across percentiles in 2005
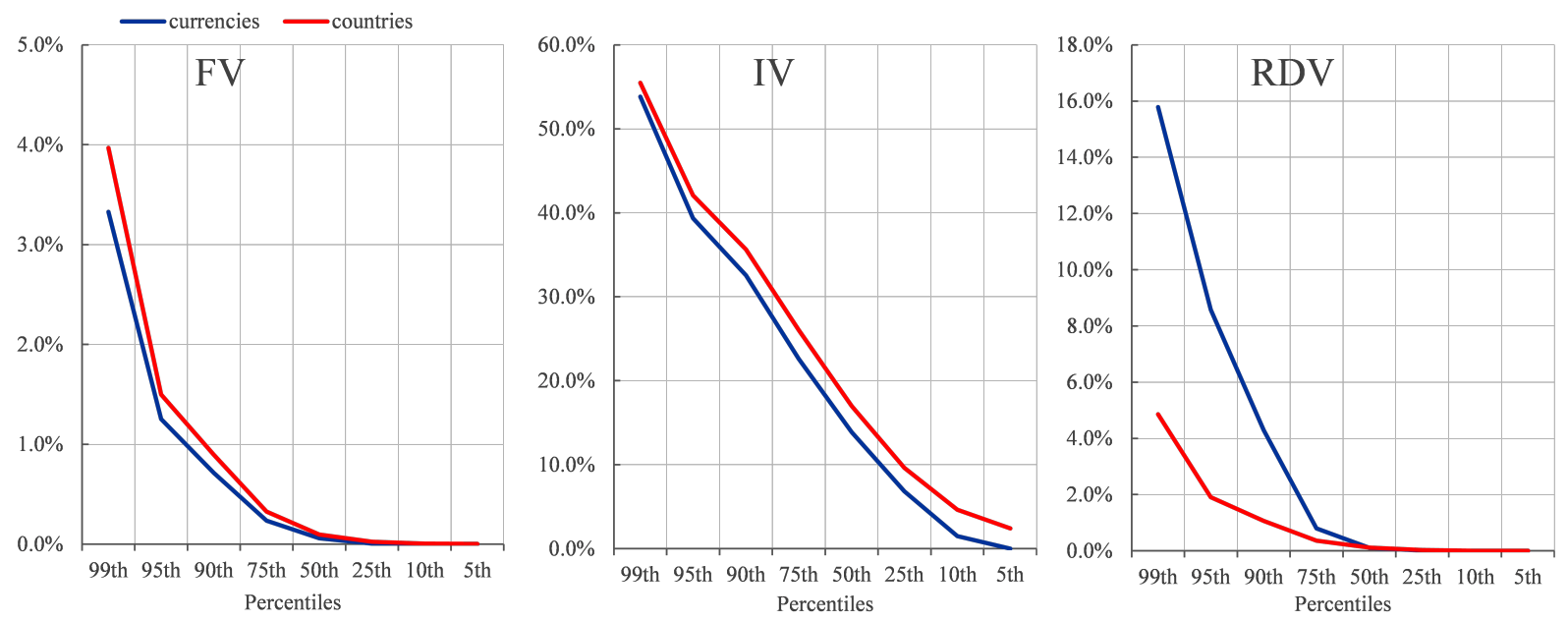

Source: World Input-Output tables (2013 release).

Note: The percentiles are for nominal exports of goods and services and computed for each bilateral country-sector-todestination observation.

The levels and the evolution over time of our indices differ from those of the country-based indices, Figure 7. The median $F V$ and $I V$ measures based on currency declined much more

\footnotetext{
${ }^{19}$ To be comparable to our $F V$ measure, the $F V$ based on countries only considers value added from the "direct importer", which is T11 and T12 in Wang et al. (2013) terminology.
} 
Figure 7: Currency and country-based GVC participation indices over time
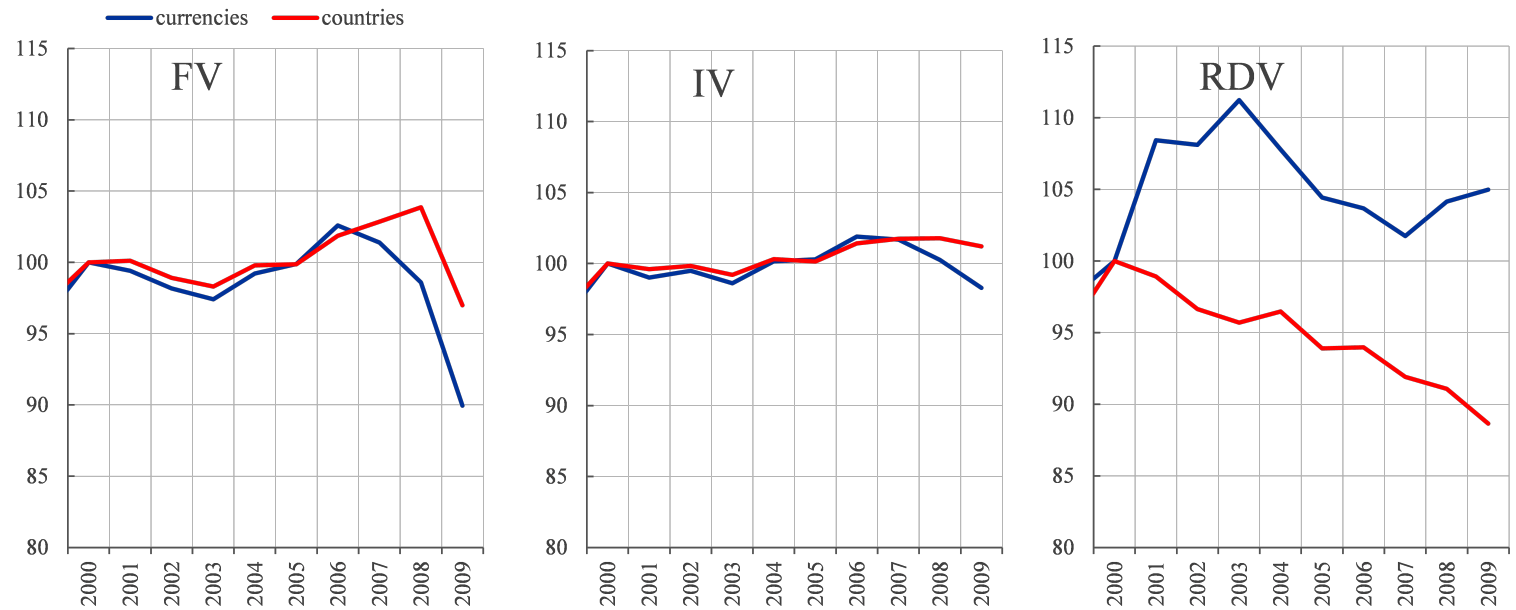

Source: World Input-Output tables (2013 release).

Note: The ratios are based on nominal exports of goods and services and computed over each bilateral country-sector to country exports and are calculated as the median across all country-sectors and indexed $=100$ in 2000 .

strongly during the Great Recession than the ones based on countries. The $R D V$ index has, however, increased strongly compared with the index based on countries. ${ }^{20}$ This is unsurprising, since 1999 and over the 2000s, many countries in the sample joined the Economic and Monetary Union of the European Union (EMU). That is also the point of our analysis: if we take the argument about GVCs and exchange rate elasticities seriously, we need to jointly take into account all links in GVCs and currency movements on the export elasticities.

The 100 country-sectors with the highest average GVC participation across the three indices are presented in Appendix C. It is clear that downstream sectors (transport equipment, electrical and optical equipment, and manufacturing, n.e.c.) in mainly Canada and Mexico stand out. These sectors are largely connected to value chains in the United States and use a large share of value added that originated there to produce final goods exports to the United States. As for $I V$, the linkages are the strongest in mainly the transporting sectors (water transport and other transporting and auxiliary transport activities), sectors selling raw materials (basic and fabricated metals and mining and quarrying) and financial intermediation. The other upstream measure, $R D V$, is strongest for the United States in the raw materials sectors (basic and fabricated metals and mining and quarrying) and manufacturing (electrical and optical equipment and rubber and plastics). It is also quite significant in the raw materials

\footnotetext{
${ }^{20}$ This might indicate that extra-euro area supply chain-related flows fell more steeply during the Great Recession, suggesting that the regional chains were more resilient to the trade slowdown and the large global value chain disruption during this period.
} 
sectors in the Slovak Republic.

\section{Empirical estimates}

Guided by our simple theoretical framework and armed with the country-sector-destination panel data set and our currency-based indices of GVC participation, we proceed to estimate how each index affect the export elasticities. Although we have dealt with one important difference between the simple theoretical framework and the data another remain.

In the model, the elasticity of substitution between domestic and foreign inputs is identical for all sectors and countries and does not vary over time. In the data, these elasticities will vary across sectors and countries. Our regressions will therefore include sector-destination-time or sector-origin-time fixed effects in order to exploit only the within sector variation.

\subsection{Specification}

Our main specification is presented in equation (15). It is designed to investigate (i) how changes in trade volume changes correlate with exchange rate movements, and (ii) how this association is itself modified by both upstream and downstream GVC participation. In our specification, $\Delta$ denotes the $\log$ change between period $t$ and $t-1$ and $F E$ denotes a set of fixed effects which are discussed below. Table 2 describes the variables used in the regressions.

Table 2: Variables used in the regressions

\begin{tabular}{c|l|c}
\hline Variable & \multicolumn{1}{|c}{ Description } & Unit \\
\hline $\mathrm{X}_{\text {osdt }}$ & Real gross exports by origin-sector to destination. & Values \\
\hline Demand \\
sdt & $\begin{array}{l}\text { Real gross imports by sector-destination, excluding im- } \\
\text { ports from the origin. }\end{array}$ & Values \\
\hline $\mathrm{exr}_{\text {odt }}$ & Bilateral exchange rate between origin-destination. & Currency units \\
\hline $\mathrm{neer}_{d t}$ & Nominal effective exchange rate of the destination. & Index \\
\hline $\mathrm{FV}_{\text {osdt }}$ & $\begin{array}{l}\text { Foreign value added in gross exports of the origin- } \\
\text { sector, sourced from the destination. }\end{array}$ & $\%$ of gross exports \\
\hline $\mathrm{IV}_{\text {osdt }}$ & $\begin{array}{l}\text { Value added in gross exports that are re-exported by } \\
\text { the first destination to another final destination. }\end{array}$ & $\%$ of gross exports \\
\hline $\mathrm{RDV}_{\text {osdt }}$ & $\begin{array}{l}\text { Value added in gross exports that return to a country } \\
\text { with the same currency as the origin. }\end{array}$ & $\%$ of gross exports \\
\hline
\end{tabular}

Changes in export volumes of sector $s$ in country $o$ to destination $d, \Delta X_{o s d t}$, fluctuates with $e x r_{\text {odt }}$ (the bilateral nominal exchange rate between $o$ and $d$ ) and $\Delta$ Demand $_{s d t}$, which is the import demand of the destination-sector. As described in Section 3, the export elasticities are 
themselves affected by upstream linkages via $F V$, as well as downstream linkages. Therefore, the bilateral exchange rate between $o$ and $d$ is interacted with the indices $F V_{o s d t}, R D V_{o s d t}$, and $I V_{o s d t}$ in order to test for the effect on the elasticities.

$$
\begin{aligned}
& \Delta X_{\text {osdt }}=\beta_{D} \Delta \text { Demand }_{s d t}+\beta_{\text {exr }} \Delta e x r_{\text {odt }}+\beta_{\text {exr FV }} \Delta e x r_{\text {odt }} F V_{o s d t} \\
& +\beta_{\text {exr IV }} \Delta e x r_{o d t} I V_{o s d t}+\beta_{\text {exr } R D V} \Delta e x r_{o d t} R D V_{o s d t}+ \\
& +\beta_{\text {neer }} \Delta \text { neer }_{d t}+\beta_{\text {neer IV }} \Delta \text { neer }_{d t} I V_{\text {sodt }}+F E+u_{\text {osdt }}
\end{aligned}
$$

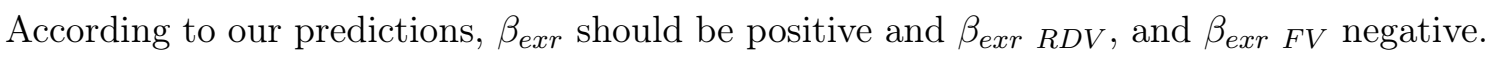
A depreciation of country o's currency vis-à-vis destination $d$ increases exported volume. However, the effect is reduced as sector $s$ 's exports contains value added coming from the destination market $d$ (a higher $F V_{o s d t}$ ) and the greater the share of domestic value added which returns back to the exporting country as re-imports (higher $R D V_{o s d t}$ ). By contrast, the effect of $I V_{o s d t}$ on the bilateral exchange rate elasticity should instead be negligible, but is expected to create a dependence between exported volume and exchange rates with countries further downstream in the supply chain. Therefore we also include the trading partners nominal effective exchange rate $\left(\right.$ neer $\left._{d t}\right)$ as well as its interaction with $I V\left(\beta_{\text {neer } I V}\right)$ in our specification. The predictions about the role of $I V$ derived from our theoretical framework is actually stronger than what is tested here. Indeed, we showed that intermediated trade flows (i.e. trade flows of the $I V$ form) are sensitive to the exchange rate between the origin country and the country of final destination. Such a prediction, however, is based on the assumption that all trade flows happen during the same period so that transit countries simply disappear from the relationship between exports and exchange rate. In this empirical setup, we account for possible delays as we formally test for the relationship between a country's $I V$ exports and the first partner's nominal effective exchange rate. We expect $\beta_{\text {neer } I V}$ to be positive.

\subsection{Empirical results}

Table 3 reports the results for the export volumes regression. ${ }^{21}$ The pooled OLS reveals a dampening effect of $F V$ on the bilateral exchange rate elasticity and the positive effect of $I V$ on the elasticity of exports to the direct partner's nominal effective exchange rate (NEER). One limitation of such a specification lies in the fact that it does not control for either supply or demand factors that could influence export flows. For example, countries might experience different trends for particular sector's export or import irrespective of exchange rate fluctua-

\footnotetext{
${ }^{21}$ Origin and destination country dummies take into account the formation of the EMU along the sample.
} 
tions. $^{22}$

We then introduce sector-destination (S-D) fixed effects in the second and third columns as well as origin-sector-destination (O-S-D) fixed effects in the fourth and fifth columns and control for different time-specific effects. Introducing O-S-D fixed effects controls for the different trends in the export volume of each sector between each pair of country. For example, if there are differential structural transformation processes across countries leading to a trend in the increase in exports in a particular sector, ${ }^{23}$ then the linear part of such a trend is captured by our O-S-D fixed effects. Furthermore, introducing origin-year fixed effects (in the third and fifth columns) is a way to capture supply side time specific shocks that would affect production and exports coming from a given country. Moreover, as explained above, changes in demand conditions in the destination country in a particular sector are controlled for using our $\Delta$ Demand $_{s d t}$ variable. $^{24}$

In most specifications, we obtain a negative and significant coefficient for the interaction terms of the bilateral exchange rate with $F V$ and $R D V$ and an insignificant effect of $I V$ on the exchange rate elasticity. Interestingly, the coefficient of the destination's NEER visà-vis its trading partners is not significant, whereas its interaction with $I V$ is positive and significant, meaning that sector $s^{\prime}$ exports are more sensitive to its direct trading partners nominal effective exchange rate the higher is the quantity of exports that are intermediated by the latter. The results are confirmed even when controlling for time-varying characteristics of countries/currencies with country-time dummies, although the interaction of $I V$ with the NEER of the destination market becomes statistically insignificant, but remains of the correct sign.

Finally, the sixth column presents results when we substitute origin-sector-destination (OS-D) fixed effects with destination-sector-year (D-S-Y) fixed-effects, in order to control for destination characteristics varying over sector and time which might affect export elasticities, such as demand conditions, trade costs or tariffs. Overall, the results are confirmed, although the effect on $F V$ on the bilateral exchange rate elasticity of exports weakens.

As we saw in Figure 6-7 and the tables in Appendix C, country-sectors are differently engaged in GVCs. How their export volumes reaches to the same changes in bilateral exchange rates depends on the specific nature of their global value chain linkages. Figures 8 through

\footnotetext{
${ }^{22}$ Our specification is written in first differences which implies the level of exports, exchange rate and total demand are not relevant in the discussion since we are only using the change of these variable in the estimation.

${ }^{23}$ For example, this could be the case regarding the increase in some specific manufacturing sectors' exports from China to the United States.

${ }^{24}$ Note that if one introduces both origin-year and destination-year fixed effects, then the coefficient on exchange rate cannot be identified because the combination of fixed effects controls for relative prices.
} 
10 plot the exchange rate elasticities computed at various percentile values of $F V, R D V$ and $I V$ to illustrate this heterogeneity. Sectors at or above the $25^{\text {th }}$ percentile of $F V$ and $R D V$ shares, that is, at the corresponding value of 0.011 and 0.019 , respectively see a dampening effect on their bilateral exchange rate elasticity of exports. ${ }^{25}$ Sectors which are very integrated in GVCs (those at the $95^{\text {th }}$ percentile or higher, or equivalently, with shares of either $F V$ and $R D V$ greater than 1.4 and 7.7), eventually see a strong reduced impact on exports from an exchange rate depreciation. ${ }^{26}$

As for the interactive effect of $I V$ with the destination market's nominal effective exchange rate, we can see that sectors within the $10^{\text {th }}$ percentile of the $I V$ distribution are insensitive to destination's exchange rate movements. However, as $I V$ increases, the elasticity of sectors $s^{\prime}$ exports to NEER rises until it reaches a value of 0.09 , meaning that if the nominal effective exchange rate increases by 1 percentage point (i.e., sector $s^{\prime}$ currency depreciates), it will stimulate sectoral exports by around 0.1 percentage point. Sectors located in this highest percentile of the $I V$ distribution are basic metals, transport, mining and quarrying and financial intermediation (Table 10 in Appendix C).

If a sector has a high $F V$ and simultaneously has a relatively high $R D V$, or vice-versa, its exports could actually decline following a depreciation of its bilateral exchange rate. This is shown in Figure 11. At the $99^{\text {th }}$ percentile of both $F V$ and $R D V^{27}$, a sectors' exports would fall following a depreciation of its bilateral exchange rate. The intuition is simple: Take as a polar case a sector that imports a significant share of its inputs from abroad, sells its products abroad as intermediate and the final products are then re-imported back for domestic consumption. In such a case, because of the foreign value added, a depreciation would increase the production price in domestic currency. Moreover, since final demand is located at home, consumers simply see an increase in the final price and hence decrease their consumption. ${ }^{28}$

\footnotetext{
${ }^{25}$ The reader should be reminded that $F V$ and $R D V$ are bilateral measures considering the share of sector's export of foreign value added and re-imported value added from the specific destination country.

${ }^{26}$ The negative coefficients shown in Figures 8 and 9 are not significant at any confidence level.

${ }^{27}$ Sectors with the highest percentiles of $F V$ and $R D V$ are reported in Table 9 in Appendix C.

${ }^{28}$ Note that this is the predicted value based on point estimates on average. It does not necessarily mean that the negative elasticity will have to be observed at all points in time.
} 
Table 3: Export regression

\begin{tabular}{lcccccc}
\hline Dependent variable: & $(1)$ & $(2)$ & $(3)$ & $(4)$ & $(5)$ & $(6)$ \\
$\Delta X$ & & & & & & \\
\hline & & & & & & \\
$\Delta e x r$ & $0.243^{* * *}$ & $0.180^{* * *}$ & $0.219^{*}$ & $0.192^{* * *}$ & $0.256^{* *}$ & $0.154^{* *}$ \\
$\Delta$ Demand & $(0.015)$ & $(0.062)$ & $(0.125)$ & $(0.055)$ & $(0.126)$ & $(0.065)$ \\
& $0.521^{* * *}$ & $0.485^{* * *}$ & $0.485^{* * *}$ & $0.487^{* * *}$ & $0.485^{* * *}$ & \\
$\Delta e x r \times i v$ & $(0.007)$ & $(0.017)$ & $(0.018)$ & $(0.018)$ & $(0.019)$ & \\
& -0.000 & 0.003 & -0.001 & 0.001 & -0.003 & 0.004 \\
$\Delta e x r \times r d v$ & $(0.001)$ & $(0.003)$ & $(0.002)$ & $(0.003)$ & $(0.002)$ & $(0.003)$ \\
& -0.003 & $-0.019^{* *}$ & -0.010 & $-0.022^{* *}$ & -0.012 & $-0.024^{* *}$ \\
$\Delta e x r \times f v$ & $(0.004)$ & $(0.009)$ & $(0.008)$ & $(0.010)$ & $(0.008)$ & $(0.010)$ \\
$\Delta$ neer & $-0.030^{* *}$ & $-0.074^{* * *}$ & $-0.049^{* *}$ & $-0.083^{* * *}$ & $-0.056^{* *}$ & -0.039 \\
$\Delta$ neer $\times i v$ & $(0.015)$ & $(0.027)$ & $(0.024)$ & $(0.029)$ & $(0.025)$ & $(0.029)$ \\
& $0.205^{* * *}$ & 0.009 & 0.070 & 0.004 & 0.089 & \\
Observations & $(0.021)$ & $(0.072)$ & $(0.124)$ & $(0.067)$ & $(0.124)$ & \\
R-squared & $0.003^{* * *}$ & $0.008^{* *}$ & 0.004 & $0.008^{* *}$ & 0.003 & $0.008^{* *}$ \\
FE & $(0.001)$ & $(0.003)$ & $(0.003)$ & $(0.003)$ & $(0.003)$ & $(0.004)$ \\
cluster & 664,271 & 664,271 & 664,271 & 664,271 & 664,271 & 664,271 \\
dummies & 0.010 & 0.018 & 0.041 & 0.049 & 0.070 & 0.107 \\
& no & S-D & S-D & O-S-D & O-S-D & D-S-Y \\
no & no & O-Y & O-Y & O-Y & O-Y & O-Y \\
& no & Y & O-Y & Y & O-Y & no \\
\hline
\end{tabular}

Notes: Robust standard errors in parentheses. ${ }^{* * *} \mathrm{p}<0.01,{ }^{* *} \mathrm{p}<0.05,{ }^{*} \mathrm{p}<0.1$. Estimation results of equation $(15)$. Observations are at sector-origin-destination-level. $\mathrm{S}=$ sector, $\mathrm{O}=$ origin country, $\mathrm{D}=$ destination country and $\mathrm{Y}=$ year. 
Figure 8: Effect of FV on the bilateral exchange rate elasticity

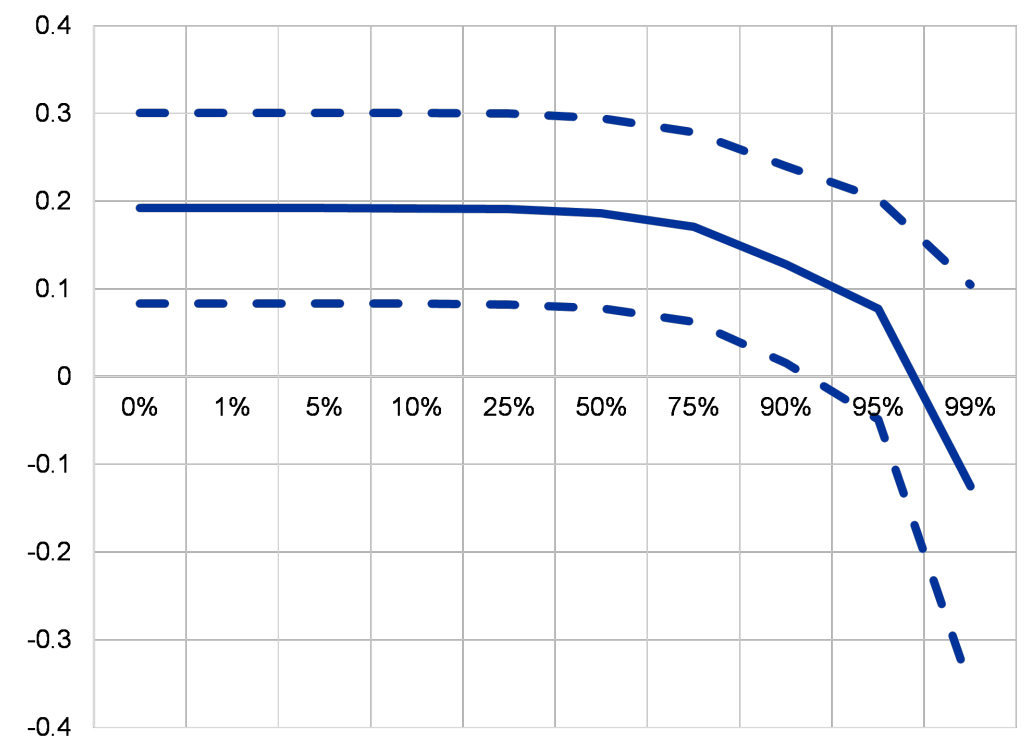

Source: World Input-Output tables (2013 release), Bank for International Settlements (BIS) and authors' calculations. Note: The Figure reports percentiles of $F V$ with respective values in the second row of the $\mathrm{x}$-axis and the corresponding exchange rate elasticity on the vertical axis. Elasticities are computed from the specification in column (4) of Table 3, including origin-sector-destination fixed effects and time dummies.

Figure 9: Effect of RDV on the bilateral exchange rate elasticity

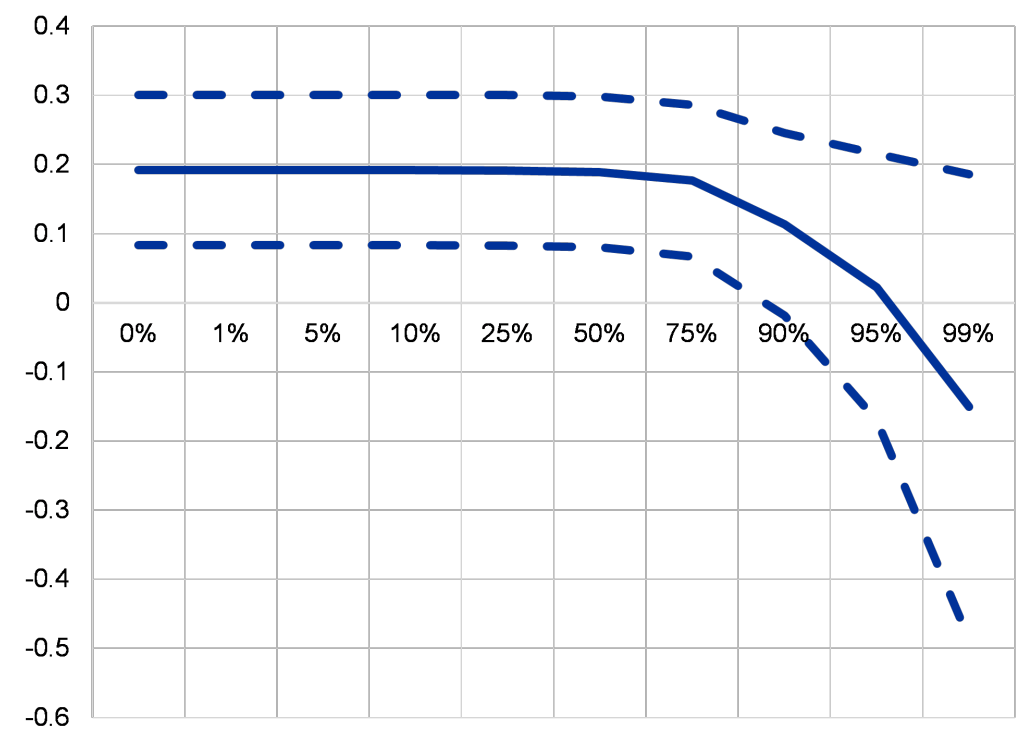

Source: World Input-Output tables (2013 release), Bank for International Settlements (BIS) and authors' calculations. Note: The Figure reports percentiles of $R D V$ with respective values in the second row of the $\mathrm{x}$-axis and the corresponding exchange rate elasticity on the vertical axis. Elasticities are computed from the specification in column (4) of Table 3, including origin-sector-destination fixed effects and time dummies.

What is the relative impact of the various ways of participating in GVCs on the ex- 
Figure 10: Effect of IV on destination's exchange rate elasticity

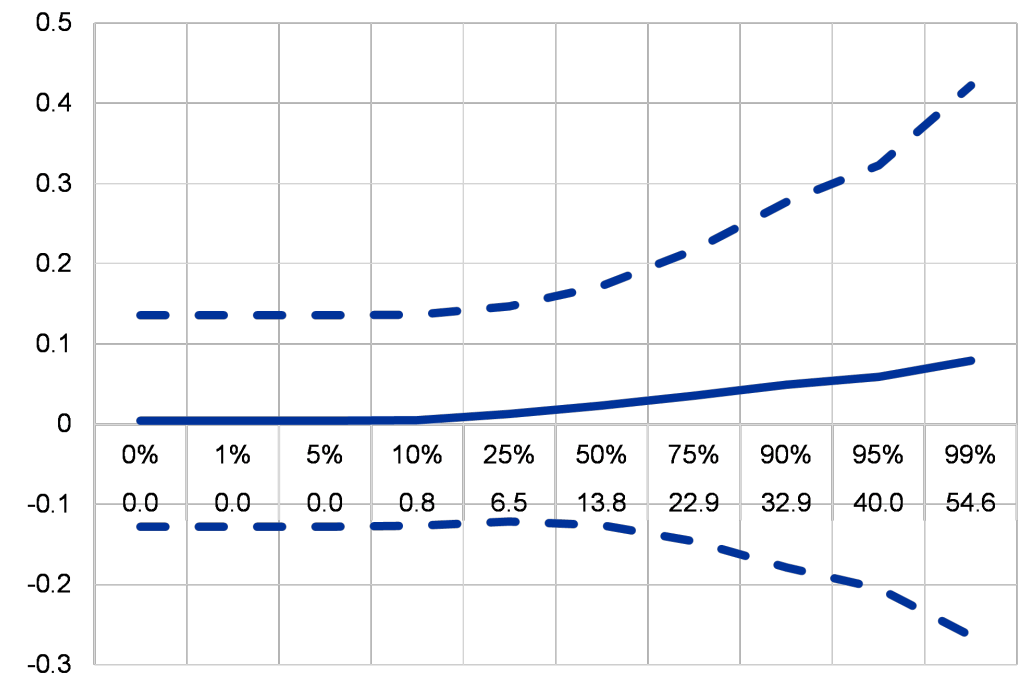

Source: World Input-Output tables (2013 release), Bank for International Settlements (BIS) and authors' calculations. Note: The Figure reports percentiles of $I V$ with respective values in the second row of the x-axis and the corresponding exchange rate elasticity on the vertical axis. Elasticities are computed from the specification in column (4) of Table 3, including origin-sector-destination fixed effects and time dummies.

change rate elasticity of export volumes? Figure 12 shows the average impact from $F V$ and $R D V$ across origin-sector-destinations on the exchange rate elasticity of exports for all origin-countries in the sample (on the x-axis). Recall that the exchange rate impact on export volumes is 0.192 without any global value chain participation and the negative sign in the figure notes the decrease from that baseline elasticity (set equal to 0). For countries furthest to the right (Russia, Portugal and Brazil), there is only a small dampening exchange rate impact of participation in GVCs, whereas the impact is greatest among countries furthest to the left (Mexico, Canada and Ireland).

As we see in the figure, the elasticities among economies in the Economic Monetary Union (EMU) in Europe and economies with large domestic markets like the United States are heavily impacted by downstream linkages $(R D V)$, which accounts for a large proportion of the dampening impact of GVCs. This tells us that not only are the most commonly investigated upstream linkages $(F V)$ important for muting the response of exports to movements in the exchange rate (see for example Amiti et al. 2014), but for large currency areas like the euro area or large domestic markets like the United States, downstream linkages are even more important in affecting the elasticities. In contrast for small open economies, the lower trade elasticities are primarily driven by upstream linkages $(F V)$. 
Figure 11: Effect of FV and RDV on the bilateral exchange rate elasticity

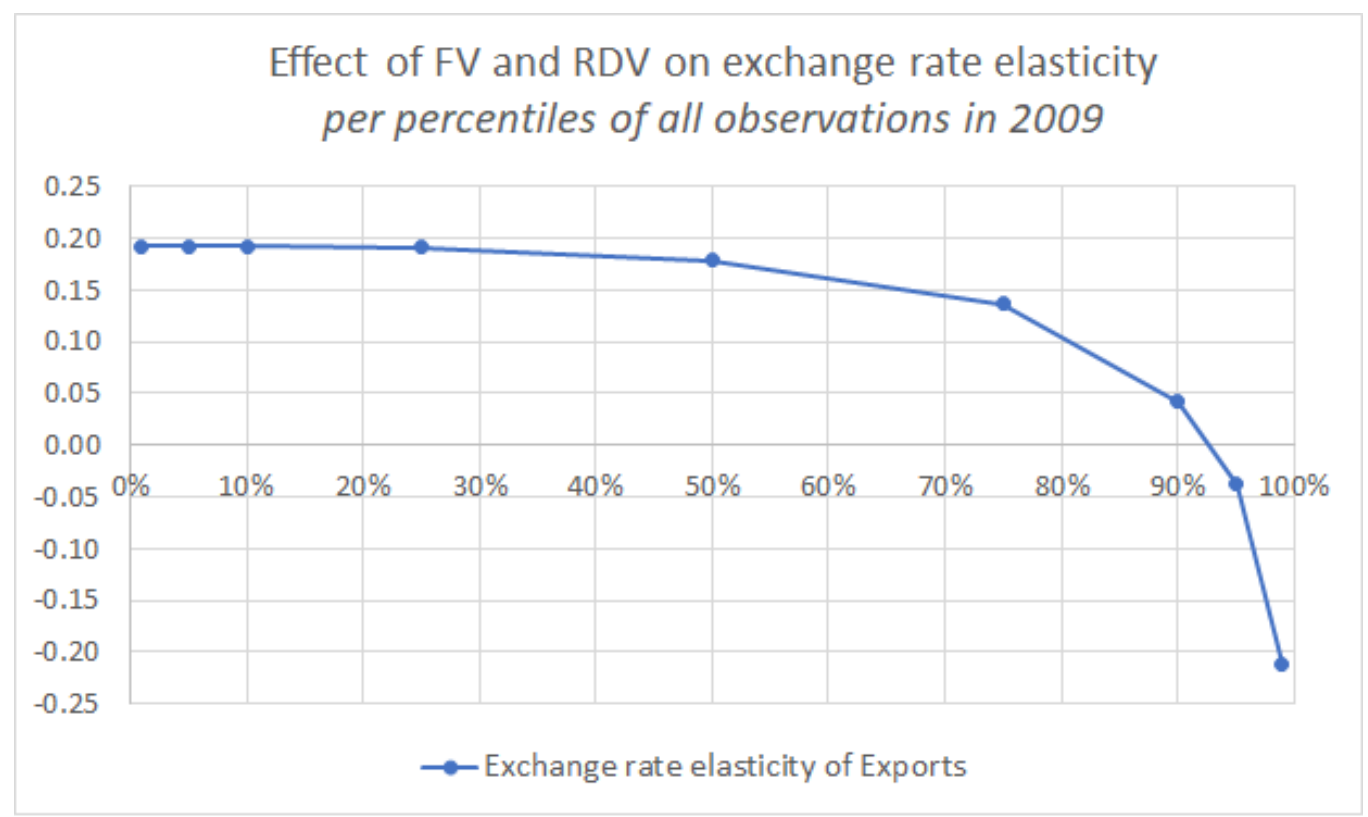

Source: World Input-Output tables (2013 release), Bank for International Settlements (BIS) and authors' calculations. Note: The horizontal axis corresponds to the different quantiles of GVC participation according to the weighted sum of FV and RDV indices, with weights corresponding to the marginal impact of the indices on export elasticities from the specification in column (4) of Table 3, including origin-sector-destination fixed effects and time dummies. The curve plots the corresponding elasticity of export volumes to exchange rates. For sectors with the highest level of both FV and RDV (at the far right of the graph), the corresponding elasticity is negative, meaning that a devaluation would decrease exports.

\subsection{The role of the US-dollar exchange rate}

Recent research has highlighted the fact that trade flows are largely invoiced in a small number of currencies, where the US-dollar is the most prominent ("dominant currency paradigm", see Gopinath et al., 2020). The US-dollar exchange rate can therefore be more important in determining bilateral export prices and volumes among non-US countries. In order to take this into account, as a robustness check, we include in regression (15) the log change of the bilateral exchange rate of the destination country $d$ vis-à-vis the US dollar $\left(\Delta e x r_{\$ d t}\right)$. We exclude observations where the US is exporter or importer from the sample as this would cause identification issues. ${ }^{29}$ Tables 5 and 6 in Appendix B summarize our results. To start with, the US dollar turns out to be significant in the price regression (see results for the baseline regression for prices in Appendix A), implying that export prices in the destination country are sensitive to changes in its exchange rate vis-à-vis the US dollar. However, differently from

\footnotetext{
${ }^{29}$ When observations with the US as destination are included, there is no fluctuation in $\Delta e x r_{\$ d t}$ and this would influence the precision of the estimated coefficients. On the other hand, if observations with the US as origin are included then $\Delta e x r_{\$ d t}$ is equal to $\Delta e x r_{o d t}$ and this would cause identification issues.
} 
Figure 12: Total effect of FV and RDV on the exchange rate elasticity across countries

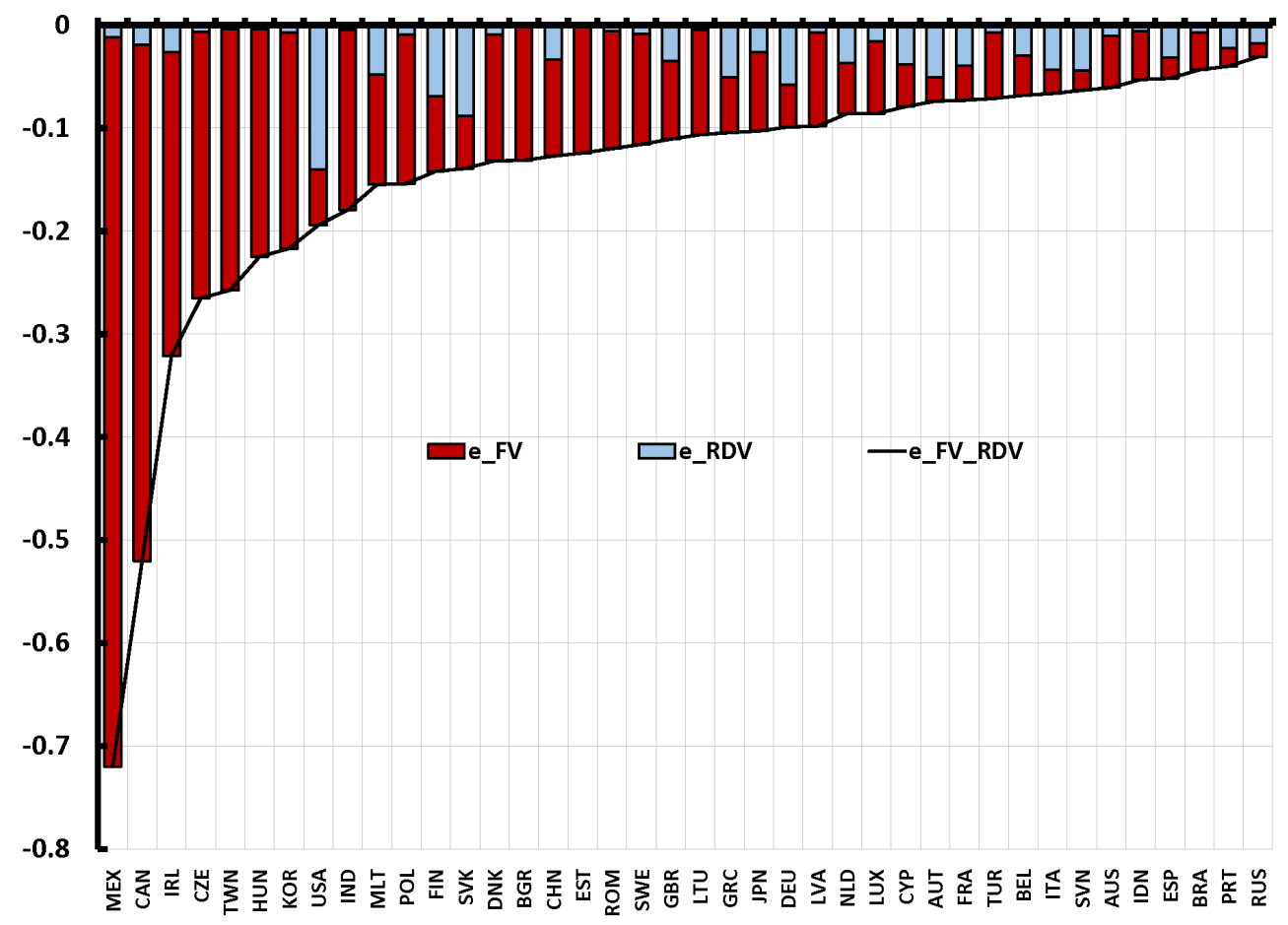

Source: World Input-Output tables (2013 release), Bank for International Settlements (BIS) and authors' calculations. Note: The figure reports the total impact from $F V$ and $R D V$ on the exchange rate elasticity of exports of a given country across the origin-sector-destination dimension in 2008 (on the vertical axis). Elasticities are computed from the specification in column (4) of Table 3, including origin-sector-destination fixed effects and time dummies and aggregated using export weights.

Gopinath et al. (2020) - who find an overwhelming effect of the dollar dominating that of the bilateral exchange rate - the effects of the two exchange rates are quantitatively similar. Most importantly, the interaction term with $F V$ remains significant although slightly smaller. As regards the export volumes regression, the elasticity of exports to the US dollar is not significant (except for the simple OLS regression, where it turns out to be also wrongly signed). This is again in contrast with Gopinath et al. (2020) findings and possibly suggests that there are other types of effects at play besides the rigidity of prices in the invoicing currency used, e.g. rigidities related to market structure and goods' quality or price rigidities further down the production chain (including on the distribution side). Moreover, our sample of countries and destinations is different from Gopinath et al. (2020) and we also focus on sectoral bilateral exports and also include other sectors than manufacturing trade which is the focus of Gopinath 
et al. (2020). Relatedly, as shown in Lyonnet et al. (2021), the limited role of US-dollar fluctuations in our sample might also be linked with firm-level useage of hedging instruments. Indeed, access to hedging instruments increases the probability of pricing in a foreign currency. Hence, to the extent that firms in service sectors have a different access to hedging products than manufacturing firms, the sectoral composition of our dataset might explain the different quantitative role of US-dollar compared to other studies.

Overall, our key coefficients related to the interaction with the GVC variables remain broadly significant in most specifications.

\section{Conclusions}

The exchange rate elasticity of export volumes constitute a key element in macroeconomics. This elasticity is in turn impacted by structural changes in the global economy and particularly by international production linkages, which have expanded strongly over the past decades. These structural changes have occurred in tandem with the expansion of common currency areas such as the EMU.

In this paper, we developed a partial equilibrium, multi-country model of international trade in intermediate inputs and final goods. With the model, we derived simple predictions for the role of precisely defined indices of GVC participation in shaping the relationship between the exchange rate, export prices and exports volumes. We validated these predictions with empirical estimates by using a comprehensive multi-country panel data set.

The results show that the exchange elasticity of export volumes decreases with the share of inputs bought in foreign currency and used to produce exports due to a price effect, similar to Amiti et al. (2014). But export volumes are also impacted by downstream conditions in the value chain. The share of a sector's exports that returns to the origin country - or in another country within the same currency area as the exporting country - also reduces the exchange rate elasticity of export volumes. In fact, some sectors that are both highly integrated "downstream" and "upstream" in the value chain actually see their exports decline when their exchange rate depreciates against the destination country. Moreover, the share of intermediate exports used to produce products that are further exported to a third currency zone by the trading partner makes bilateral trade flows sensitive to the trading partner's exchange rate.

To precisely assess the consequences of international input-output linkages on exchange rate elasticities, we have emphasized the importance of defining indices of GVC participation based on currencies rather than countries. In our sample, the share of exports that are re-imported 
tends to decrease over time when based on countries, whereas it actually increases when we compute it based on currencies. On the other hand, the fall in the share of foreign value added in exports in recent years seems more pronounced when we take into account the fact that many countries share the same currency (in particular in the EMU).

These additional elements are important since they imply that participation in GVCs as defined in the literature is not necessarily associated with a decrease in the responsiveness of exports to exchange rates: if international linkages are regional and with countries sharing the same currency, they might not significantly lessen the responsiveness of exports to changes in exchange rates. Future developments in international production fragmentation and their impact on export elasticities will therefore also depend on the future scope of common currency areas. 


\section{References}

Acemoglu, D., Akcigit, U., and Kerr, W. (2016). Networks and the macroeconomy: An empirical exploration. NBER Macroeconomics Annual, 30:273-335.

Ahmed, S., Appendino, M. A., and Ruta, M. (2017). Global value chains and the exchange rate elasticity of exports. B.E. Journal of Macroeconomics, 17:1:1-24.

Amiti, M., Itskhoki, O., and Konings, J. (2014). Importers, exporters, and exchange rate disconnect. American Economic Review, 104(7):1942-78.

Arbatli, E. and Hong, G. H. (2016). Singapore's export elasticities: A disaggregated look into the role of global value chains and economic complexity. IMF Working Papers, (No. 16/52).

Auboin, M. and Ruta, M. (2013). The relationship between exchange rates and international trade: a literature review. World Trade Review, 12(3):577-605.

Auer, R. A., Chaney, T., and SaurÂl', P. (2018). Quality pricing-to-market. Journal of International Economics, 110:87 - 102.

Bems, R. and Johnson, R. C. (2017). Demand for value added and value-added exchange rates. American Economic Journal: Macroeconomics, 9(4):45-90.

Bernini, M. and Tomasi, C. (2015). Exchange rate pass-through and product heterogeneity: Does quality matter on the import side? European Economic Review, 77:117 - 138.

Boz, E., Gopinath, G., and Plagborg-Møller, M. (2017). Global trade and the dollar. Technical report, National Bureau of Economic Research.

Burstein, A. T., Neves, J. C., and Rebelo, S. (2003). Distribution costs and real exchange rate dynamics during exchange-rate-based stabilizations. Journal of Monetary Economics, 50(6):1189- 1214 .

Campa, J. M. and Gonzalez Minguez, J. M. (2006). Differences in exchange rate pass-through in the euro area. European Economic Review, 50(1):121 - 145.

Chen, N. and Juvenal, L. (2016). Quality, trade, and exchange rate pass-through. Journal of International Economics, 100:61 - 80.

Conerly, M. D. and Mansfield, E. R. (1989). An approximate test for comparing independent regression models with unequal error variances. Journal of econometrics, 40(2):239-259. 
de Soyres, F. and Gaillard, A. (2020). Value added and productivity linkages across countries. Working Paper.

Demian, C.-V. and di Mauro, F. (2017). The exchange rate, asymmetric shocks and asymmetric distributions. International Economics.

Duval, R., Li, N., Saraf, R., and Seneviratne, D. (2016). Value-added trade and business cycle synchronization. Journal of International Economics, 99:251-262.

ECB (2017). The impact of global value chains on the macroeconomic analysis of the euro area. ECB, Economic Bulletin, 8.

Fauceglia, D., Lassmann, A., Shingal, A., and Wermelinger, M. (2014). Backward participation in global value chains and exchange rate driven adjustments of swiss exports. Study on behalf of the State Secretariat for Economic Affairs SECO.

Georgiadis, G. and Gräb, J. (2019). Global value chain participation and exchange rate passthrough to export and import prices. Economic Bulletin Articles, 5.

Goldberg, L. and Campa, J. (2010). The sensitivity of the cpi to exchange rates: Distribution margins, imported inputs, and trade exposure. The Review of Economics and Statistics, 92:392-407.

Gopinath, G., Boz, E., Casas, C., DÃnez, F. J., Gourinchas, P.-O., and Plagborg-MÃ̈̈ller, M. (2020). Dominant currency paradigm. American Economic Review, 110(3):677-719.

Imbs, J. and Mejean, I. (2017). Trade elasticities. Review of International Economics, $25(2): 383-402$.

Johnson, R. C. (2014). Trade in intermediate inputs and business cycle comovement. American Economic Journal: Macroeconomics, 6(4):39-83.

Johnson, R. C. and Noguera, G. (2012). Proximity and production fragmentation. American Economic Review, 102(3):407-11.

Johnson, R. C. and Noguera, G. (2017). A portrait of trade in value-added over four decades. Review of Economics and Statistics, 99(5):896-911.

Koopman, R., Wang, Z., and Wei, S.-J. (2014). Tracing value-added and double counting in gross exports. American Economic Review, 104(2):459-94. 
Krugman, P. and Taylor, L. (1978). Contractionary effects of devaluation. Journal of International Economics, 8(3):445-456.

Leigh, M. D., Lian, W., Poplawski-Ribeiro, M., Szymanski, R., Tsyrennikov, V., and Yang, H. (2017). Exchange Rates and Trade: A Disconnect? International Monetary Fund.

Los, B., Timmer, M. P., and de Vries, G. J. (2015). How global are global value chains? a new approach to measure international fragmentation. Journal of regional science, 55(1):66-92.

Lyonnet, V., Martin, J., and Mejean, I. (2021). Invoicing currency, firm size, and hedging. Journal of Money, Credit and Banking.

Ollivaud, P., Rusticelli, E., and Schwellnus, C. (2015). The changing role of the exchange rate for macroeconomic adjustment. OECD Economics Department Working Papers.

Rose, A. K. (1991). The role of exchange rates in a popular model of international trade: Does the "marshall-lerner" condition hold? Journal of International Economics, 30(3-4):301-316.

Timmer, M. P., Dietzenbacher, E., Los, B., Stehrer, R., and Vries, G. J. (2015). An illustrated user guide to the world input-output database: the case of global automotive production. Review of International Economics, 23(3):575-605.

Timmer, M. P., Los, B., Stehrer, R., de Vries, G. J., et al. (2016). An anatomy of the global trade slowdown based on the wiod 2016 release. Technical report, Groningen Growth and Development Centre, University of Groningen.

Wang, Z., Wei, S.-J., and Zhu, K. (2013). Quantifying international production sharing at the bilateral and sector levels. Technical report, National Bureau of Economic Research.

Yi, K. (2003). Can vertical specialization explain the growth of world trade? Journal of Political Economy, 111(1):52-102. 


\section{A Prices regression}

In this section, we explore the role of production linkages in reducing the exchange rate passthrough to export prices, using specification (16) below.

\section{A.1 Specification}

In this specification, $\Delta$ denotes the $\log$ change between period $t$ and $t-1$ and $F E$ is a set of fixed effects. $\Delta p_{\text {sodt }}$ is the change of export price produced by sector $s$ in country $o$ and sold in destination $d$, expressed in the destination's currency.

As noted in our theoretical framework, the price of a firm in any country is a function of the price of all its direct and indirect suppliers and all associated exchange rates. In our specification, we focus on the dependence on direct bilateral exchange rate, and hos this dependence is loosened by upstream participation in GVCs. ${ }^{30}$

Export prices fluctuate with the bilateral exchange rate, $\Delta e x r_{\text {odt }}$, but this dependence itself is expected to diminish with upstream GVC participation. By construction, changes in exchange rate is zero when two countries are using the same currency. We also add other sectorspecific cost measures, such as domestic labour and capital costs, $\Delta l_{\text {sot }}$ and $\Delta k_{\text {sot }}$, respectively, to control for other determinants of export prices.

$$
\Delta p_{\text {sodt }}=\beta_{\text {exr }} \Delta e x r_{\text {odt }}+\beta_{\text {exr fv }} \Delta e x r_{\text {odt }} f v_{\text {sodt }}+\beta_{l} \Delta l_{\text {sot }}+\beta_{k} \Delta k_{\text {sot }}+F E+u_{\text {sodt }}
$$

The coefficient of interest in (16) is $\beta_{\text {exrfv }}$ - that is, the coefficient of the interaction of exchange rate with $f v_{\text {sodt }}$. We expect that an exchange rate depreciation (increase in $\Delta e x r_{\text {odt }}$ ) reduces sector $s$ ' prices to destination $d$. However, this effect is loosened if exports contain value added originating from $d$, as measured by $f v_{\text {sodt }}$. Therefore, we expect $\beta_{\text {exr } f v}$ to be positive and reduce the exchange rate pass-through.

\section{A.2 Price pass-through}

We start with results from a pooled OLS regression featuring only the exchange rate changes and changes in capital and labour costs as regressors, in order to estimate the full pass-through of exchange rate into destination prices. A currency depreciation (appreciation) of $1 \%$ leads to a decrease (increase) in export prices of about $-0.7 \%$. The coefficient does not fall dramatically

\footnotetext{
${ }^{30}$ In practical terms, our specification assumes that bilateral exchange rates are not correlated, which allows us to focus on the interaction between GVC participation and exchange rate pass-through using the bilateral exchange rate.
} 
when adding the sector-destination (column 2) or the origin-sector-destination (column 3) fixed effects and time dummies.

When the interaction between exchange rates and the $F V$ index is included, the exchange rate pass-through is diminished, as the sign of the coefficient is positive and significant in Table 4. In particular, as Figure 13 points out, for sectors falling within the $50^{\text {th }}$ percentile of the $F V$ distribution, the exchange rate pass-through remains unchanged. As the share of foreign intermediate inputs in exports increases, the pass-through is reduced substantially, falling to a value of -0.39. Overall, these results are in line with those of Amiti et al. (2014) and Fauceglia et al. (2014) who also find evidence of declining exchange rate pass-through when the import content of exports increases. 
Table 4: Exchange rate pass-through to export prices

\begin{tabular}{|c|c|c|c|c|c|c|c|c|c|}
\hline $\begin{array}{l}\text { Dependent variable: } \\
\Delta p\end{array}$ & (1) & $(2)$ & (3) & $(4)$ & $(5)$ & $(6)$ & (7) & (8) & (9) \\
\hline$\Delta e x r$ & $\begin{array}{c}-0.770 * * * \\
(0.001)\end{array}$ & $\begin{array}{c}-0.736^{* * *} \\
(0.034)\end{array}$ & $\begin{array}{c}-0.754^{* * *} \\
(0.037)\end{array}$ & $\begin{array}{c}-0.761^{* * *} \\
(0.034)\end{array}$ & $\begin{array}{c}-0.946^{* * *} \\
(0.013)\end{array}$ & $\begin{array}{c}-0.783^{* * *} \\
(0.036)\end{array}$ & $\begin{array}{c}-0.948^{* * *} \\
(0.014)\end{array}$ & $\begin{array}{c}-0.450 * * * \\
(0.067)\end{array}$ & $\begin{array}{c}-0.960^{* * *} \\
(0.013)\end{array}$ \\
\hline$\Delta e x r \times f v$ & & & & $\begin{array}{c}0.149^{* * *} \\
(0.023)\end{array}$ & $\begin{array}{c}0.062^{* * *} \\
(0.016)\end{array}$ & $\begin{array}{c}0.173^{* * *} \\
(0.025)\end{array}$ & $\begin{array}{c}0.079^{* * *} \\
(0.017)\end{array}$ & $\begin{array}{l}0.018 \\
(0.017)\end{array}$ & $\begin{array}{c}0.062^{* * *} \\
(0.016)\end{array}$ \\
\hline$\Delta k$ & $\begin{array}{c}0.086^{* * *} \\
(0.001)\end{array}$ & $\begin{array}{c}0.085^{* * *} \\
(0.008)\end{array}$ & $\begin{array}{c}0.080^{* * *} \\
(0.008)\end{array}$ & $\begin{array}{c}0.084^{* * * *} \\
(0.008)\end{array}$ & $\begin{array}{c}0.051^{* * * *} \\
(0.006)\end{array}$ & $\begin{array}{c}0.079^{* * * *} \\
(0.008)\end{array}$ & $\begin{array}{c}0.052^{* * * *} \\
(0.006)\end{array}$ & $\begin{array}{c}0.063^{* * *} \\
(0.007)\end{array}$ & \\
\hline$\Delta l$ & $\begin{array}{c}0.364^{* * *} \\
(0.001)\end{array}$ & $\begin{array}{c}0.345^{* * *} \\
(0.043)\end{array}$ & $\begin{array}{c}0.310^{* * *} \\
(0.057)\end{array}$ & $\begin{array}{c}0.341^{* * *} \\
(0.042)\end{array}$ & $\begin{array}{c}0.078^{* * *} \\
(0.015)\end{array}$ & $\begin{array}{c}0.306^{* * *} \\
(0.055)\end{array}$ & $\begin{array}{c}0.081^{* * *} \\
(0.016)\end{array}$ & $\begin{array}{c}0.212^{* * *} \\
(0.025)\end{array}$ & \\
\hline Observations & 638,871 & 638,871 & 638,871 & 638,871 & 638,871 & 638,871 & 638,871 & 638,871 & 638,871 \\
\hline R-squared & 0.565 & 0.584 & 0.614 & 0.587 & 0.742 & 0.618 & 0.757 & 0.761 & 0.875 \\
\hline $\mathrm{FE}$ & no & S-D & S-D & O-S-D & O-S-D & O-S-D & O-S-D & D-S-Y & O-S-Y \\
\hline cluster & no & $\mathrm{O}-\mathrm{Y}$ & $\mathrm{O}-\mathrm{Y}$ & $\mathrm{O}-\mathrm{Y}$ & $\mathrm{O}-\mathrm{Y}$ & $\mathrm{O}-\mathrm{Y}$ & $\mathrm{O}-\mathrm{Y}$ & $\mathrm{O}-\mathrm{Y}$ & $\mathrm{O}-\mathrm{Y}$ \\
\hline dummies & no & $\mathrm{Y}$ & $\mathrm{Y}$ & $\mathrm{Y}$ & $\mathrm{O}-\mathrm{Y}$ & $\mathrm{Y}$ & $\mathrm{O}-\mathrm{Y}$ & no & no \\
\hline
\end{tabular}

Notes: Robust standard errors in parentheses. ${ }^{* * *} \mathrm{p}<0.01,{ }^{* *} \mathrm{p}<0.05,{ }^{*} \mathrm{p}<0.1$. Estimation results of equation (16). Observations are at sector-origin-destination-level. $\mathrm{S}=$ sector, $\mathrm{O}=$ origin country, $\mathrm{D}=$ destination country and $\mathrm{Y}=$ year. 
Figure 13: Effect of FV on exchange rate pass-through

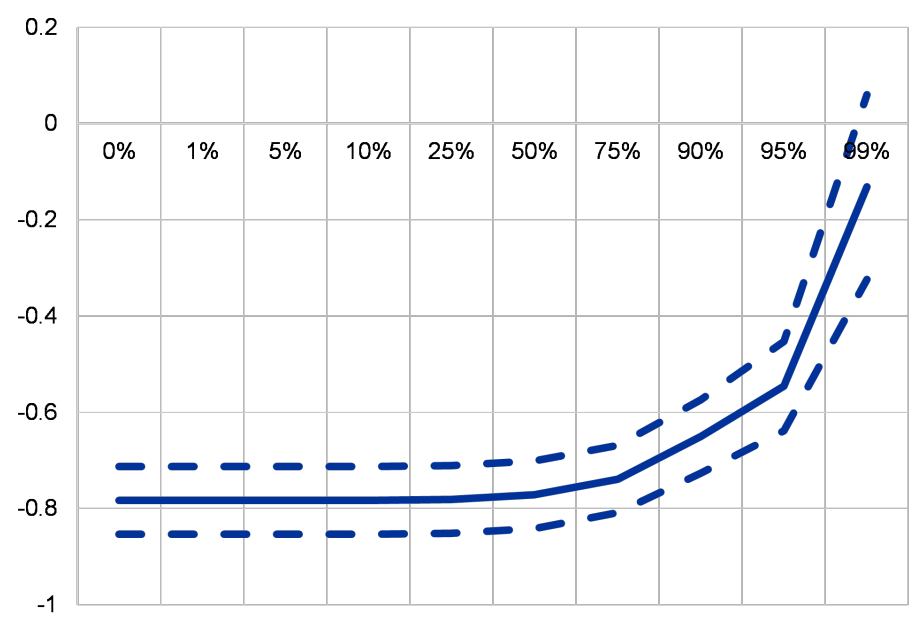

Source: World Input-Output tables (2013 release), Bank for International Settlements (BIS) and authors' calculations. Note: The Figure reports percentiles of $F V$ with respective values in the second row of the x-axis and the corresponding exchange rate elasticity on the vertical axis. Elasticities are computed from the specification in column (6) of Table 4, including origin-sector-destination fixed effects and time dummies. 


\section{B The role of the dollar}

Table 5: Exchange rate pass-through to export prices with US dollar exchange rate

\begin{tabular}{|c|c|c|c|c|c|c|c|c|c|}
\hline $\begin{array}{l}\text { Dependent variable: } \\
\Delta p\end{array}$ & (1) & $(2)$ & (3) & $(4)$ & (5) & (6) & (7) & (8) & (9) \\
\hline$\Delta e x r_{\$}$ & $\begin{array}{c}0.335^{* * *} \\
(0.001)\end{array}$ & $\begin{array}{c}0.495^{* * *} \\
(0.069)\end{array}$ & $\begin{array}{c}0.472^{* * *} \\
(0.074)\end{array}$ & $\begin{array}{c}0.485^{* * *} \\
(0.069)\end{array}$ & $\begin{array}{c}2.972^{* * *} \\
(1.090)\end{array}$ & $\begin{array}{c}0.460^{* * *} \\
(0.073)\end{array}$ & $\begin{array}{c}3.111^{* * *} \\
(1.119)\end{array}$ & & $\begin{array}{c}2.846^{* * *} \\
(1.036)\end{array}$ \\
\hline$\Delta e x r$ & $\begin{array}{c}-0.554^{* * *} \\
(0.001)\end{array}$ & $\begin{array}{c}-0.445^{* * *} \\
(0.067)\end{array}$ & $\begin{array}{c}-0.467^{* * *} \\
(0.072)\end{array}$ & $\begin{array}{c}-0.464^{* * * *} \\
(0.068)\end{array}$ & $\begin{array}{l}2.046^{*} \\
(1.099)\end{array}$ & $\begin{array}{c}-0.490^{* * *} \\
(0.072)\end{array}$ & $\begin{array}{l}2.185^{*} \\
(1.128)\end{array}$ & $\begin{array}{c}-0.453^{* * *} \\
(0.067)\end{array}$ & $\begin{array}{l}1.903^{*} \\
(1.044)\end{array}$ \\
\hline$\Delta e x r \times f v$ & & & & $\begin{array}{c}0.084^{* * *} \\
(0.021)\end{array}$ & $\begin{array}{c}0.049^{* *} \\
(0.020)\end{array}$ & $\begin{array}{c}0.109^{* * *} \\
(0.024)\end{array}$ & $\begin{array}{c}0.065^{* * *} \\
(0.022)\end{array}$ & $\begin{array}{c}0.029 \\
(0.021)\end{array}$ & $\begin{array}{r}0.048^{* *} \\
(0.020)\end{array}$ \\
\hline$\Delta k$ & $\begin{array}{c}0.072^{* * *} \\
(0.001)\end{array}$ & $\begin{array}{c}0.067^{* * *} \\
(0.007)\end{array}$ & $\begin{array}{c}0.063^{* * *} \\
(0.007)\end{array}$ & $\begin{array}{c}0.066^{* * *} \\
(0.007)\end{array}$ & $\begin{array}{c}0.052^{* * *} \\
(0.006)\end{array}$ & $\begin{array}{c}0.063^{* * *} \\
(0.006)\end{array}$ & $\begin{array}{c}0.052^{* * *} \\
(0.006)\end{array}$ & $\begin{array}{c}0.064^{* * *} \\
(0.007)\end{array}$ & \\
\hline$\Delta l$ & $0.258^{* * *}$ & $0.206^{* * *}$ & $0.185^{* * *}$ & $0.207^{* * *}$ & $0.078^{* * *}$ & $0.184^{* * *}$ & $0.080^{* * *}$ & $0.212^{* * *}$ & \\
\hline Observations & 605,764 & 605,764 & 605,764 & 605,764 & 605,764 & 605,764 & 605,764 & 605,764 & 605,764 \\
\hline R-squared & 0.609 & 0.631 & 0.655 & 0.632 & 0.745 & 0.656 & 0.760 & 0.761 & 0.877 \\
\hline $\mathrm{FE}$ & no & S-D & O-S-D & S-D & O-S-D & O-S-D & O-S-D & D-S-Y & O-S-Y \\
\hline cluster & no & $\mathrm{O}-\mathrm{Y}$ & $\mathrm{O}-\mathrm{Y}$ & $\mathrm{O}-\mathrm{Y}$ & $\mathrm{O}-\mathrm{Y}$ & $\mathrm{O}-\mathrm{Y}$ & $\mathrm{O}-\mathrm{Y}$ & $\mathrm{O}-\mathrm{Y}$ & $\mathrm{O}-\mathrm{Y}$ \\
\hline dummies & no & $\mathrm{Y}$ & $\mathrm{Y}$ & $\mathrm{Y}$ & $\mathrm{O}-\mathrm{Y}$ & $\mathrm{Y}$ & $\mathrm{O}-\mathrm{Y}$ & no & no \\
\hline
\end{tabular}

Notes: Robust standard errors in parentheses. ${ }^{* * *} \mathrm{p}<0.01,{ }^{* *} \mathrm{p}<0.05,{ }^{*} \mathrm{p}<0.1$. Estimation results of equation (16). Observations are at sector-origin-destination-level. $\mathrm{S}=$ sector, $\mathrm{O}=$ origin country, $\mathrm{D}=$ destination country and $\mathrm{Y}=$ year. 
Table 6: Export regression with US dollar exchange rate

\begin{tabular}{|c|c|c|c|c|c|c|}
\hline $\begin{array}{l}\text { Dependent variable: } \\
\Delta X\end{array}$ & (1) & (2) & (3) & (4) & $(5)$ & (6) \\
\hline$\Delta e x r_{\$}$ & $\begin{array}{c}0.587^{* * * *} \\
(0.021)\end{array}$ & $\begin{array}{c}0.037 \\
(0.143)\end{array}$ & $\begin{array}{c}0.994 \\
(1.977)\end{array}$ & $\begin{array}{c}0.019 \\
(0.146)\end{array}$ & $\begin{array}{l}1.026 \\
(1.993)\end{array}$ & \\
\hline$\Delta e x r$ & $\begin{array}{c}0.218^{* * * *} \\
(0.015)\end{array}$ & $\begin{array}{c}0.180^{* * * *} \\
(0.064)\end{array}$ & $\begin{array}{l}1.206 \\
(1.980)\end{array}$ & $\begin{array}{c}0.196^{* * *} \\
(0.058)\end{array}$ & $\begin{array}{l}1.279 \\
(1.991)\end{array}$ & $\begin{array}{c}0.153^{* *} \\
(0.066)\end{array}$ \\
\hline$\Delta$ Demand & $\begin{array}{c}0.623 * * * \\
(0.008)\end{array}$ & $\begin{array}{c}0.482^{* * *} \\
(0.018)\end{array}$ & $\begin{array}{c}0.480^{* * *} \\
(0.019)\end{array}$ & $\begin{array}{c}0.484^{* * *} \\
(0.019)\end{array}$ & $\begin{array}{c}0.480^{* * * *} \\
(0.019)\end{array}$ & \\
\hline$\Delta e x r \times i v$ & $\begin{array}{c}0.001 \\
(0.001)\end{array}$ & $\begin{array}{c}0.003 \\
(0.003)\end{array}$ & $\begin{array}{l}-0.001 \\
(0.002)\end{array}$ & $\begin{array}{c}0.002 \\
(0.003)\end{array}$ & $\begin{array}{l}-0.002 \\
(0.002)\end{array}$ & $\begin{array}{c}0.004 \\
(0.003)\end{array}$ \\
\hline$\Delta e x r \times r d v$ & $\begin{array}{l}-0.001 \\
(0.005)\end{array}$ & $\begin{array}{l}-0.015 \\
(0.009)\end{array}$ & $\begin{array}{l}-0.010 \\
(0.008)\end{array}$ & $\begin{array}{l}-0.018 \\
(0.011)\end{array}$ & $\begin{array}{l}-0.012 \\
(0.009)\end{array}$ & $\begin{array}{l}-0.020^{*} \\
(0.011)\end{array}$ \\
\hline$\Delta e x r \times f v$ & $\begin{array}{c}-0.087^{* * *} \\
(0.017)\end{array}$ & $\begin{array}{c}-0.093^{* * *} \\
(0.034)\end{array}$ & $\begin{array}{c}-0.064^{* *} \\
(0.030)\end{array}$ & $\begin{array}{c}-0.108^{* * *} \\
(0.036)\end{array}$ & $\begin{array}{c}-0.076^{* *} \\
(0.033)\end{array}$ & $\begin{array}{l}-0.053 \\
(0.033)\end{array}$ \\
\hline$\Delta$ neer & $\begin{array}{c}-0.419^{* * *} \\
(0.031)\end{array}$ & $\begin{array}{l}-0.032 \\
(0.135)\end{array}$ & $\begin{array}{c}0.049 \\
(0.128)\end{array}$ & $\begin{array}{l}-0.019 \\
(0.137)\end{array}$ & $\begin{array}{c}0.070 \\
(0.130)\end{array}$ & \\
\hline$\Delta n e e r \times i v$ & $\begin{array}{c}0.005^{* * *} \\
(0.001)\end{array}$ & $\begin{array}{c}0.009^{* * *} \\
(0.003)\end{array}$ & $\begin{array}{c}0.004 \\
(0.003)\end{array}$ & $\begin{array}{c}0.008^{* *} \\
(0.003)\end{array}$ & $\begin{array}{c}0.003 \\
(0.003)\end{array}$ & $\begin{array}{r}0.008^{* *} \\
(0.004)\end{array}$ \\
\hline Observations & 630,424 & 630,424 & 630,424 & 630,424 & 630,424 & 630,424 \\
\hline R-squared & 0.010 & 0.018 & 0.041 & 0.049 & 0.070 & 0.107 \\
\hline $\mathrm{FE}$ & no & S-D & S-D & O-S-D & O-S-D & D-S-Y \\
\hline cluster & no & $\mathrm{O}-\mathrm{Y}$ & $\mathrm{O}-\mathrm{Y}$ & $\mathrm{O}-\mathrm{Y}$ & $\mathrm{O}-\mathrm{Y}$ & $\mathrm{O}-\mathrm{Y}$ \\
\hline dummies & no & $\mathrm{Y}$ & $\mathrm{O}-\mathrm{Y}$ & $\mathrm{Y}$ & $\mathrm{O}-\mathrm{Y}$ & no \\
\hline
\end{tabular}

Notes: Robust standard errors in parentheses. ${ }^{* * *} \mathrm{p}<0.01,{ }^{* *} \mathrm{p}<0.05,{ }^{*} \mathrm{p}<0.1$. Estimation results of equation (15) including the delta log of destination's bilateral exchange rate with the US dollar $\left(\Delta e x r_{\$ d t}\right)$. Observations are at sector-origin-destination-level. $\mathrm{S}=$ sector, $\mathrm{O}=$ origin country, $\mathrm{D}=$ destination country and $\mathrm{Y}=$ year. 


\section{Further descriptive statistics}

Table 7: Ranking of sectors according to the currency-based FV index

\begin{tabular}{|c|c|}
\hline country & sector name \\
\hline CAN & Transp ort Equipment \\
\hline MEX & Electrical and Optical Equipment \\
\hline MEX & Manufacturing, Nec; Recycling \\
\hline MEX & Textiles and Textile Products \\
\hline MEX & Machinery, Nec \\
\hline MEX & Rubber and Plastics \\
\hline CAN & Rubber and Plastics \\
\hline MEX & Transp ort Equipment \\
\hline MEX & Pulp, Paper, Paper, Printing and Publishing \\
\hline CAN & Electrical and Optical Equipment \\
\hline MLT & Pulp, Paper, Paper, Printing and Publishing \\
\hline CAN & Chemicals and Chemical Prodvcts \\
\hline CAN & Machinery, Nec \\
\hline MEX & Food, Bevera ges and Tobacco \\
\hline CAN & Leather, Lea ther and Footwear \\
\hline CAN & Manufacturing, Nec; Recycling \\
\hline BGR & Leather, Leather and Footwear \\
\hline MEX & Leather, Leather and Footwear \\
\hline MEX & Basic Metals and Fabricated Metal \\
\hline IRL & Wood and Products of Wood and Cork \\
\hline CAN & Basic Metals and Fabricated Metal \\
\hline BGR & Coke, Refined Petroleum and Nuclear Fuel \\
\hline CAN & Textiles and Textile Products \\
\hline IND & Manufacturing, Nec; Recycling \\
\hline CAN & Other Non-Metallic Mineral \\
\hline CAN & Food, Beverages and Tobacco \\
\hline CAN & Pulp, Paper, Paper, Printing and Publishing \\
\hline MEX & Wood and Products of Wood and Cork \\
\hline HUN & Transp ort Equipment \\
\hline TwN & Water Tran port \\
\hline GRC & Air Transport \\
\hline CAN & Coke, Refined Petroleum and Nuclear Fuel \\
\hline CAN & Air Transport \\
\hline IRL & Food, Bevera ges and Tobacco \\
\hline CAN & Construction \\
\hline IRL & A griculture, Hun ting, Foresty and Fishing \\
\hline MEX & A griculture, Hun ing, Foresty and Fishing \\
\hline MEX & Chemicals and Chemical Prodvcts \\
\hline CZE & Electrical and Optical Equipment \\
\hline IRL & Electrical and Optical Equipment \\
\hline IRL & Financial Intermediation \\
\hline IRL & Leather, Lea ther and Footwear \\
\hline MEX & Air Transport \\
\hline IRL & Other Non-Metallic Mineral \\
\hline CAN & Wholesale Trade and Commission Trade \\
\hline CZE & Transp ort Equipment \\
\hline CAN & Wood and Products of Wood and Cork \\
\hline IRL & Textiles and Textile Products \\
\hline CZE & Manufacturing, Nec; Recycling \\
\hline IRL & Hotels and Restaurants \\
\hline
\end{tabular}

\begin{tabular}{|c|c|}
\hline country & sector name \\
\hline MEX & Other Non-Metallic Mineral \\
\hline CZE & Machinery, Nec \\
\hline DNK & Air Transport \\
\hline IRL & Chemicals and Chemical Products \\
\hline HUN & Textiles and Textile Products \\
\hline HUN & Leather, Leather and Footwear \\
\hline TWN & Sale, Maintenance and Repair of Motor Vehicles \\
\hline TWN & Electrical and Optical Equipment \\
\hline IRL & Rubber and Plastics \\
\hline HUN & Manufacturing, Nec; Recycling \\
\hline IRL & Transport Equipment \\
\hline MEX & Coke, Refined Petroleum and Nuclear Fuel \\
\hline BGR & Sale, Maintenance and Repair of Motor Vehicles \\
\hline IRL & Air Transport \\
\hline KOR & Electrical and Optical Equipment \\
\hline BGR & Inland Transport \\
\hline CZE & Pulp, Paper, Paper, Printing and Publishing \\
\hline CAN & Agriculture, Hunting, Foresty and Fishing \\
\hline TWN & Air Transport \\
\hline HUN & Electrical and Optical Equipment \\
\hline MLT & Hotels and Restaurants \\
\hline ROM & Leather, Leather and Footwear \\
\hline CZE & Rubber and Plastics \\
\hline IRL & Machinery, Nec \\
\hline IDN & Machinery, Nec \\
\hline SWE & Coke, Refined Petroleum and Nuclear Fuel \\
\hline HUN & Machinery, Nec \\
\hline IRL & Post and Telecommunications \\
\hline CAN & Renting of M\&Eq and Other Business Activities \\
\hline TWN & Machinery, Nec \\
\hline TWN & Agriculture, Hunting, Foresry and Fishing \\
\hline IRL & Manufacturing, Nec; Recycling \\
\hline IRL & Water Transp ort \\
\hline KOR & Machinery, Nec \\
\hline KOR & Water Transport \\
\hline TWN & Food, Beverages and Tobacco \\
\hline IRL & Coke, Refined Petroleum and Nuclear Fuel \\
\hline ROM & Textiles and Textile Products \\
\hline HUN & Rubber and Plastics \\
\hline POL & Transport Equipment \\
\hline MEX & Electricity, Gas and Water Supply \\
\hline IRL & Mining and Quarrying \\
\hline POL & Manufacturing, Nec; Recycling \\
\hline BGR & Chemicals and Chemical Products \\
\hline CAN & Sale, Maintenance and Rep air of Motor Vehicles \\
\hline CAN & Health and Social Work \\
\hline TWN & Chemicals and Chemical Products \\
\hline TWN & Rubber and Plastics \\
\hline CZE & Leather, Lea ther and Footwear \\
\hline MEX & Renting of M\&Eq and Other Business Activities \\
\hline
\end{tabular}

Notes: The table shows the first 100 sectors with the highest value of the currency-based FV index. The index is calculated as a weighted average of destination specific indices, where the weight is the share of each destination over total gross exports. 
Table 8: Ranking of sectors according to the currency-based RDV index

\begin{tabular}{|c|c|}
\hline country & sector name \\
\hline USA & Basic Metals and Fabricated Metal \\
\hline USA & Rubber and Plastics \\
\hline USA & Mining and $Q$ uarrying \\
\hline SVK & Basic Metals and Fabricated Metal \\
\hline SVK & Financial Intermediation \\
\hline USA & Electrical and Optical Equipment \\
\hline SVK & Wood and Prodvets of Wood and Cork \\
\hline USA & Textiles and Textile Products \\
\hline USA & Pulp, Paper, Paper, Printing and Publishing \\
\hline FIN & Water Tran sport \\
\hline FIN & Inland Transport \\
\hline USA & Wood and Products of Wood and Cork \\
\hline JPN & Other Supporting and Auxiliary Transport Activities \\
\hline USA & Public Admin and Defence; Compulsory Social Security \\
\hline USA & Chemicals and Chemical Products \\
\hline USA & Manufacturing, Nec; Recycling \\
\hline IRL & Edvcation \\
\hline MLT & Water Transport \\
\hline USA & Transp ort Equipment \\
\hline SVK & Chemicals and Chemical Products \\
\hline SVK & In land Transport \\
\hline MLT & Financial Intermediation \\
\hline USA & Wholesale Trade and Commission Trade \\
\hline FIN & Rubber and Plastics \\
\hline MLT & Sale, Maintenance and Repair of Motor Vehicles \\
\hline SVK & Mining and $Q$ uarrying \\
\hline SVK & Renting of M\&Eq and Other Business Activities \\
\hline SVK & Water Tran \$ort \\
\hline SVK & Construction \\
\hline SVK & Hotels and Restaur ants \\
\hline CYP & Renting of $M \& E q$ and Other Business A ctivities \\
\hline FIN & Other Supporting and Auxiliary Transport Activities \\
\hline DEU & Basic Metals and Fabricated Metal \\
\hline USA & Other Non-Metallic Mineral \\
\hline SVK & Rubber and Plastics \\
\hline FIN & Wholesale Trade and Commission Trade \\
\hline IRL & Basic Metals and Fabricated Metal \\
\hline FIN & A griculture, Hunting, Foresry and Fishing \\
\hline USA & Financial Intermediation \\
\hline CYP & Electricity, Gas and Water Supply \\
\hline SVK & Pulp, Paper, Paper, Printing and Publishing \\
\hline SVK & Other Supporting and Auxiliary Transport Activities \\
\hline MLT & Textiles and Textile Products \\
\hline DEU & Rubber and Plastics \\
\hline SVK & Sale, Maintenance and Repair of Motor Vehicles \\
\hline SVK & Agriculture, Hun ting, Foresty and Fishing \\
\hline FRA & Inland Transport \\
\hline $\mathrm{CHN}$ & Mining and Quarrying \\
\hline SVK & Wholesale Trade and Commission Trade \\
\hline USA & Renting of M\&Eq and Other Business Activities \\
\hline
\end{tabular}

\begin{tabular}{|c|c|}
\hline country & sector name \\
\hline USA & Electricity, Gas and Water Supply \\
\hline SVK & Other Non-Metallic Mineral \\
\hline MLT & In land Transport \\
\hline SVK & Air Transport \\
\hline CYP & Sale, Maintenance and Repair of Motor Vehicles \\
\hline MLT & Post and Telecommunications \\
\hline FIN & Basic Metals and Fabricated Metal \\
\hline USA & Machinery, Nec \\
\hline NLD & Education \\
\hline SVK & Retail Trade, Except of Motor Vehicles \\
\hline JPN & Sale, Maintenance and Repair of Motor Vehicles \\
\hline $\mathrm{DEU}$ & Inland Transport \\
\hline GRC & Sale, Maintenance and Repair of Motor Vehicles \\
\hline SVK & Electricity, Gas and Water Supply \\
\hline FIN & Air Transport \\
\hline USA & Other Supporting and Auxiliary Transport Activities \\
\hline FIN & Textiles and Textile Products \\
\hline FIN & Retail Trade, Except of Motor Vehicles \\
\hline MLT & Pulp, Paper, Paper, Printing and Publishing \\
\hline BEL & Education \\
\hline FIN & Post and Telecommunications \\
\hline SVK & Edvcation \\
\hline $\mathrm{DEU}$ & Water Transp ort \\
\hline IRL & Agriculture, Hunting, Foresty and Fishing \\
\hline IRL & Wood and Products of Wood and Cork \\
\hline PRT & Mining and Quarrying \\
\hline GRC & Basic Metals and Fabricated Metal \\
\hline GRC & Rubber and Plastics \\
\hline USA & Post and Telec ommunications \\
\hline FIN & Renting of M\&Eq and Other Business Activities \\
\hline AUT & Rubber and Plastics \\
\hline GRC & Mining and Quarrying \\
\hline FIN & Real Estate Activities \\
\hline GBR & Wholesale Trade and Commission Trade \\
\hline GBR & Agriculture, Hunting, Foresty and Fishing \\
\hline FRA & Water Transp ort \\
\hline FIN & Sale, Maintenance and Repair of Motor Vehicles \\
\hline USA & Hoels and Restaurants \\
\hline AUT & Inland Transport \\
\hline $\mathrm{CHN}$ & Chemicals and Chemical Prodvcts \\
\hline FRA & Basic Metals and Fabricated Metal \\
\hline ITA & Public Admin and Defence; Compulsory Socia1 Security \\
\hline $\mathrm{DEU}$ & Electrical and Optical Equipment \\
\hline ITA & Water Transp ort \\
\hline SVN & Post and Telecommunications \\
\hline USA & Other Community, Social and Personal Services \\
\hline ITA & Inland Transport \\
\hline SVK & Public Admin and Defence; Compulsory Socia1 Security \\
\hline MLT & Other Supporting and Auxiliary Transport Activities \\
\hline USA & Inland Transport \\
\hline
\end{tabular}

Notes: The table shows the first 100 sectors with the highest value of the currency-based RDV index. The index is calculated as a weighted average of destination specific indices, where the weight is the share of each destination over total gross exports. 
Table 9: Ranking of sectors according to the currency-based FV and RDV indices

\begin{tabular}{|c|c|}
\hline country & sector name \\
\hline CAN & Transp ort Equipment \\
\hline MEX & Electrical and Optical Equipment \\
\hline USA & Basic Metals and Fabricated Metal \\
\hline USA & Rubber and Plastics \\
\hline USA & Mining and Quarrying \\
\hline MEX & Manufacturing, Nec; Recycling \\
\hline MLT & Pulp. Paper. Paper Printing and Publishing \\
\hline CAN & Rubber and Plastics \\
\hline MEX & Rubber and Plastics \\
\hline MEX & Machinery, Nec \\
\hline MEX & Textiles and Textile Products \\
\hline SVK & Financial Intermediation \\
\hline SVK & Basic Metals and Fabricated Metal \\
\hline MEX & Transp ort Equipment \\
\hline IRL & Wood and Products of Wood and Cork \\
\hline USA & Electrical and Optical Equipment \\
\hline CAN & Electrical and Optical Equipment \\
\hline MEX & Pulp, Paper, Paper, Printing and Publishing \\
\hline SVK & Wood and Products of Wood and Cork \\
\hline USA & Textiles and Textile Products \\
\hline CAN & Chemicals and Chemical Prodvcts \\
\hline IRL & A griculture. Hun ting, Foresty and Fishing \\
\hline USA & Pulp, Paper, Paper, Printing and Publishing \\
\hline SVK & Inland Transport \\
\hline FIN & Water Tran \\
\hline USA & Wood and Products of Wood and Cork \\
\hline CAN & Basic Metals and Fabricated Metal \\
\hline CAN & Machinery, Nec \\
\hline FIN & Inland Transport \\
\hline USA & Transp ort Equipment \\
\hline MEX & Basic Metals and Fabricaed Metal \\
\hline IRL & Edvcation \\
\hline USA & Chemicals and Chemical Prodvcts \\
\hline IRL & Basic Metals and Fabricated Metal \\
\hline USA & Public Admin and Defence; Compulsory Social Security \\
\hline JPN & Other Supporting and Auxiliary Transport Activities \\
\hline USA & Manufacturing. Nec; Recucling \\
\hline MLT & Water Tran p ort \\
\hline SVK & Chemicals and Chemical Products \\
\hline IRL & Other Non-Metallic Mineral \\
\hline CAN & Leather, Lea ther and Footwear \\
\hline IRL & Rubber and Plastics \\
\hline IRL & Hotels and Restaurants \\
\hline CAN & Pulp, Paper, Paper, Printing and Publishing \\
\hline CAN & Manufacturing, Nec; Recucling \\
\hline MEX & Food. Beverages and Tobacco \\
\hline SVK & Water Tran \\
\hline CAN & Textiles and Textile Products \\
\hline CAN & Other Non-Metallic Mineral \\
\hline MEX & Leather, Lea ther and Footwear \\
\hline
\end{tabular}

\begin{tabular}{|c|c|}
\hline country & sector name \\
\hline MLT & Financial Intermediation \\
\hline GRC & Air Transport \\
\hline SVK & Other Supporting and Auxiliary Transport Activities \\
\hline BGR & Leather. Lea ther and Footwear \\
\hline MLT & Sale. Maintenance and Repair of Motor Vehicles \\
\hline CYP & Electricity, Gas and Water Supply \\
\hline FIN & Rubber and Plastics \\
\hline BGR & Coke. Refined Petroleum and Nuclear Fuel \\
\hline SVK & Hotels and Restaurants \\
\hline SVK & Air Transport \\
\hline USA & Other Non-Metallic Mineral \\
\hline MEX & Wood and Products of Wood and Cork \\
\hline IND & Manufacturing. Nec; Recycling \\
\hline IRL & Electrical and Optical Equipment \\
\hline SVK & Renting of $M \& E q$ and Other Business Activities \\
\hline SVK & Construction \\
\hline IRL & Financial Intermediation \\
\hline CAN & Food, Beverages and Tobacco \\
\hline CAN & Construction \\
\hline CAN & Coke. Refined Petroleum and Nuclear Fuel \\
\hline USA & Wholesale Trade and Commission Trade \\
\hline MEX & Chemicals and Chemical Products \\
\hline CAN & Air Transport \\
\hline IRL & Post and Telecommunications \\
\hline MEX & Agriculture. Hunting, Foresty and Fishing \\
\hline FIN & Wholesale Trade and Commission Trade \\
\hline SVK & Mining and Quarrying \\
\hline FIN & Other Supporting and Auxiliary Transport Activities \\
\hline HUN & Transport Equipment \\
\hline MLT & Textiles and Textile Products \\
\hline TWN & Water Transp ort \\
\hline CYP & Renting of $\mathrm{M \& Eq}$ and Other Business Activities \\
\hline SVK & Rubber and Plastics \\
\hline IRL & Leather. Lea ther and Footwear \\
\hline SVK & Pulp, Paper, Paper, Printing and Publishing \\
\hline DEU & Basic Metals and Fabricated Metal \\
\hline IRL & Food. Beverazes and Tobacco \\
\hline FIN & Agriculture, Hunting, Forestry and Fishing \\
\hline SVK & Electricity, Gas and Water Supply \\
\hline IRL & Water Transp ort \\
\hline IRL & Transport Equipment \\
\hline MLT & Hotels and Restaurants \\
\hline CAN & Wholesale Trade and Commission Trade \\
\hline USA & Machinery, Nec \\
\hline IRL & Textiles and Textile Products \\
\hline CAN & Wood and Prodvets of Wood and Cork \\
\hline USA & Financial Intermediation \\
\hline SVK & Other Non-Metallic Mineral \\
\hline MLT & Post and Telecommunications \\
\hline SVK & Sale, Maintenance and Repair of Motor Vehicles \\
\hline
\end{tabular}

Notes: The table shows the first 100 sectors with the highest value of the sum of the currency-based FV and RDV indices. Both indices is calculated as a weighted average of destination specific indices, where the weight is the share of each destination over total gross exports. 
Table 10: Ranking of sectors according to the currency-based IV index

\begin{tabular}{|c|c|c|c|}
\hline country & sector name & country & sector name \\
\hline TUR & Financial Intermediation & GRC & Other Supporting and Auxiliary Transport Activities \\
\hline IDN & Financial Intermediation & AUS & Water Transp ort \\
\hline IND & Other Supporting and Auxiliary Transport Activities & GBR & Mining and Quarrying \\
\hline LVA & Financial Intermediation & SWE & Basic Metals and Fabricated Metal \\
\hline IDN & Other Supporting and Auxiliary Transport Activities & BGR & Other Supporting and Auxiliary Transport Activities \\
\hline SWE & Mining and $Q$ uarrying & BEL & Financial Intermediation \\
\hline DNK & Mining and Quarrying & ESP & Financial Intermediation \\
\hline RUS & Basic Metals and Fabricated Metal & MLT & Other Supporting and Auxiliary Transport Activities \\
\hline JPN & Water Tran & IND & Water Transp ort \\
\hline GBR & Other Supporting and Auxiliary Transport Activities & LTU & Real Estate Activities \\
\hline USA & Other Supporting and Auxiliary Transport Activities & LTU & Renting of M\&Eq and Other Business Activities \\
\hline $\mathrm{POL}$ & Mining and $Q$ uarrying & LTU & Water Transport \\
\hline JPN & Other Supporting and Auxiliary Transport Activities & KOR & Financial Intermediation \\
\hline MEX & Other Supporting and Auxiliary Transport Activities & JPN & Textiles and Textile Products \\
\hline TWN & Other Supporting and Auxiliary Transport Activities & BGR & Mining and Quarrying \\
\hline BRA & Public Admin and Defence; Compulsory Social Security & SWE & Financial Intermediation \\
\hline TUR & Other Supporting and Auxiliary Transport Activities & LVA & Water Transport \\
\hline ROM & Other Supporting and Auxiliary Transport Activities & RUS & Water Transp ort \\
\hline USA & Wholesale Trade and Commission Trade & ROM & Basic Metals and Fabricated Metal \\
\hline $\mathrm{CHN}$ & Other Supporting and Auxiliary Transport Activities & CZE & Other Supporting and Auxiliary Transport Activities \\
\hline LVA & Other Supporting and Auxiliary Transport Activities & AUS & Mining and $Q$ uarrying \\
\hline BRA & Other Community, Social and Personal Services & BRA & Sale, Maintenance and Repair of Motor Vehicles \\
\hline BRA & Renting of M\&Eq and Other Business Activities & BRA & Retail Trade, Except of Motor Vehicles and Motorcycles, \\
\hline BRA & In land Transport & BRA & Wholesale Trade and Commission Trade \\
\hline BRA & Water Tran & $\mathrm{DEU}$ & Other Supporting and Auxiliary Transport Activities \\
\hline BRA & Other Supporting and Auxiliary Transport Activities & HUN & Other Supporting and Auxiliary Transport Activities \\
\hline BRA & Air Transport & DNK & Wholesale Trade and Commission Trade \\
\hline BRA & Post and Telecommunications & TUR & Inland Transport \\
\hline IDN & Mining and $Q$ varrying & RUS & Leather, Lea ther and Footwear \\
\hline RUS & Other Supporting and Auxiliary Transport Activities & AUS & Financial Intermediation \\
\hline CHN & Water Tran sp ort & BRA & Financial Intermediation \\
\hline JPN & Wholesale Trade and Commission Trade & TUR & Basic Metals and Fabricated Metal \\
\hline TUR & Water Tran sport & RUS & Rubber and Plastics \\
\hline JPN & Sale, Maintenance and Repair of Motor Vehicles & DNK & Electricity, Gas and Water Supply \\
\hline SWE & In land Transport & IDN & Water Transp ort \\
\hline RUS & Wholesale Trade and Commission Trade & LTU & Basic Metals and Fabricated Metal \\
\hline RUS & Mining and $Q$ uarrying & EST & Post and Telecommunications \\
\hline LTU & Other Supporting and Auxiliary Transport Activities & GBR & Basic Metals and Fabricated Metal \\
\hline BRA & Basic Metals and Fabricated Metal & BGR & Basic Metals and Fabricated Metal \\
\hline GBR & Financial Intermediation & GBR & Renting of M\&Eq and Other Business Activities \\
\hline GBR & Water Tran & JPN & Rubber and Plastics \\
\hline USA & Water Tran sport & IDN & Basic Metals and Fabricated Metal \\
\hline GBR & Wholesale Trade and Commission Trade & HUN & Wholesale Trade and Commission Trade \\
\hline IND & Wholesale Trade and Commission Trade & DNK & Other Supporting and Auxiliary Transport Activities \\
\hline SWE & Other Supporting and Auxiliary Transport Activities & POL & Basic Metals and Fabricated Metal \\
\hline RUS & Inland Transport & RUS & Renting of M\&Eq and Other Business Activities \\
\hline ROM & Wholesale Trade and Commission Trade & DNK & Basic Metals and Fabricated Metal \\
\hline MEX & Water Tran sport & JPN & Renting of M\&Eq and Other Business Activities \\
\hline POL & Other Supporting and Auxiliary Transport Activities & $\begin{array}{l}\text { GBR } \\
\text { CZE }\end{array}$ & Sale, Maintenance and Repair of Motor Vehicles \\
\hline & Edvcation & & Basic Metals and Fabricated Metal \\
\hline
\end{tabular}

Notes: The table shows the first 100 sectors with the highest value of the sum of the currency-based FV and RDV indices. Both indices is calculated as a weighted average of destination specific indices, where the weight is the share of each destination over total gross exports. 